\title{
PENGARUH 4P GREEN MARKETING MIX TERHADAP KEPUASAN PELANGGAN BLOOMKA SKINCARE
}

\author{
Mila Dwi Astuti ${ }^{1}$, Miguna Astuti ${ }^{2}$, Dienni Ruhjatini Sholihah ${ }^{3}$ \\ ${ }^{1}$ Fakultas Ekonomi dan Bisnis, Universitas Pembangunan Nasional Veteran Jakarta \\ Email:miladwi@upnvj.ac.id \\ ${ }^{2}$ Fakultas Ekonomi dan Bisnis, Universitas Pembangunan Nasional Veteran Jakarta \\ Email: miguna.astuti@upnvj.ac.id \\ ${ }^{3}$ Fakultas Ekonomi dan Bisnis, Universitas Pembangunan Nasional Veteran Jakarta \\ Email: dienni.rujahtni@upnvj.ac.id
}

\begin{abstract}
This study aims to analyze and prove whether there is an effect of green product, green orice, green place and green promotion on customer satisfaction. This research method is quantitative with a sample of 100 bloomka customer respondents who are domiciled in the DKI Jakarta area. The data analysis technique used is descriptive analysis and inferential analysis with Smart PLS 3.0 analysis tool. The results of this study indicate that the green product variable has an effect on customer satisfaction of 0.369. Green price has an effect on customer satisfaction of 0.286. Green place has an effect on customer satisfaction of 0.208. Green promotion has no effect on customer satisfaction.
\end{abstract}

Keywords: Customer Satisfaction; Green Product; Green Price; Green Place; Green Promotion

\section{ABSTRAK}

Penelitian ini bertujuan untuk menganalisis dan membuktikan apakah terdapat pengaruh green product, green orice, green place dan green promotion terhadap kepuasan pelanggan. Metode penelitian ini yaitu kunatitatif dengan sampel sebanyak 100 responden pelanggan bloomka yang berdomisili di wilayah DKI Jakarta. Teknik analisis data yang digunakan adalah analisis deskriptif dan analisis inferensial dengan alat analisis Smart PLS 3.0. Hasil dari penelitian ini menunjukan bahwa variabel green product berpengaruh terhadap kepuasan pelanggan sebesar 0,369. Green price berpengauh terhadap kepuasan pelanggan sebesar 0,286. Green place berpengaruh terhadap kepuasan pelanggan sebesar 0,208 . Green promotion tidak berpengaruh terhadap kepuasan pelanggan.

Kata Kunci: kepuasan pelanggan; green product; green price; green place; green promotion

\section{PENDAHULUAN}

\section{Latar Belakang}

Manusia merupakan pelaku yang menggunakan berbagai potensi alam didunia bisnis memiliki peranan sangat penting dalam membangun keseimbangan dengan lingkungan (environmentally friendly). Kasus ini didukung oleh penelitian yang telah dilaksanakan salah satu peneliti seperti (Aniza, 2011) yang memberi pernyataan bahwa "87\% orang dewasa di Amerika Serikat yang peduli terhadap kondisi lingkungan alam dan $80 \%$ percaya bahwa untuk melindungi lingkungan diperlukan suatu perubahan besar dalam gaya hidup". Sedangkan Rawat et al (2011) berpendapat bahwa " $87 \%$ populasi di India sangat ingin menyelamatkan bumi. Lain lagi dengan Murthy (2010) mengatakan bahwa dalam sebuah studi tahun 1992 dari 16 negara, lebih dari 50\% konsumen di setiap negara prihatin tentang lingkungan." Pertumbuhan industry kosmetik dan personal care selaras dengan meningkatnya perolehan target pertumbuhan sebesar tujuh persen pada tahun 2019, saat ini target yang ditunjuk Kementerian Perindustrian sebesar lebih dari Sembilan persen ditahun 2020.

Berdasarkan data I triwulan tahun 2020 yang terdapat pada Badan Pusat Statistik (BPS) bahwa industry kimia dan farmasi termasuk sector kosmetik mengaami pertumbuhan sebesar 5,59\%. Pertumbuhan ini menyatakan bahwa produksi kosmetik di Indonesia mengalami peningkatan. Peningkatan ini membawa dampak positif bagi sektor perekonomian namun berbanding lurus 
dengan meningkatnya limbah kosmetik dan personal care baik merujuk kepada ingredients yang digunakan maupun packaging. Sandy, (2020)

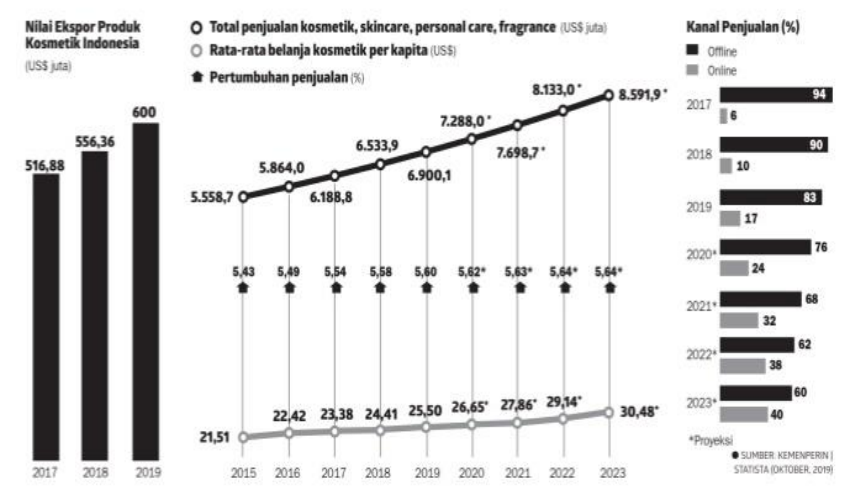

Gambar 1. Grafik Nilai Ekspor Produk Kosmetik Indonesia Sumber: Badan Pusat Statistik (BPS)

Salah satu hasil dari industri kosmetik yang semakin berkembang di Indonesia adalah Bloomka. Bloomka sendiri merupakan brand yang dilahirkan oleh PT. Mitra Kreasi Natural yang memiliki focus dan spesialisasi menggunakan bahan-bahan 100\% alami serta konsisten mengutamakan bahan bahan natural hingga memperhitungkan persentase kandungannya agar aman dan bermanfaat digunakan oleh kulit Indonesia, setiap variant Bloomka memiliki concern di masalah kulit yang spesifik. Bloomka juga memiliki campaign bahwa cantik bukan berarti sempurna tetapi bagaimana kita memperlakukan dan menjaga kulit kita serta jiwa kita dari dalam. Karena bagaimanapun, cantik itu terpancar dari dalam bukan hanya dari luar. Dalam produksinya juga Bloomka menjaga nilai nilai kelestarian lingkungan dengan menggunakan bahan bahan natural, pengemasan dilakukan dengan bahan berbasis bahan yang mudah diaur ulang dengan kertas dan tidak menggunakan bubble wrap. Berikut merupakan rating Bloomka yang diberikan customer

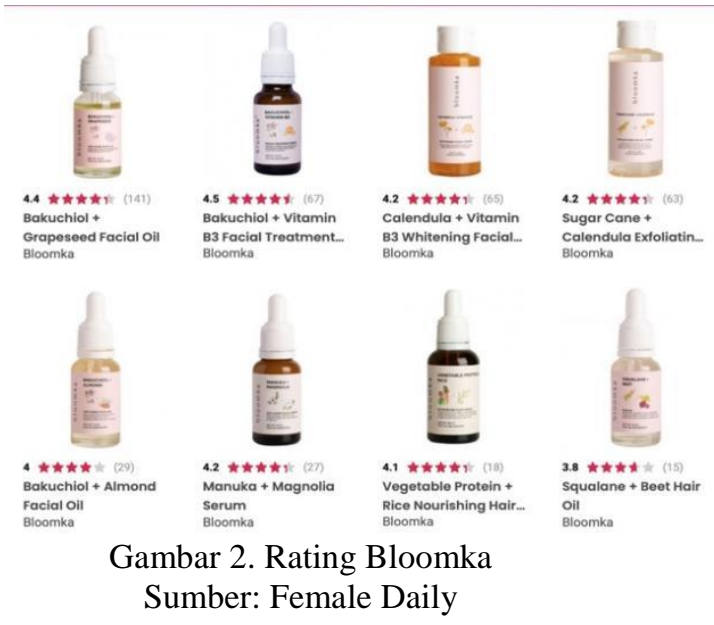

Dari rating yang tertera pada gambar diatas, kita dapat menyimpulkan bahwa rata-rata rating yang diperoleh oleh Bloomka adalah bintang 4 sampai 5 yang berarti konsumen merasa cukup puas sampai puas terhadap product Bloomka. Meskipun Bloomka memiliki awareness terhadap tanggung jawab sosialnya. Dilain pihak, konsumen tetap memiliki keluhan terhadap product Bloomka, padahal para konsumen yang menggunakan bloomka sudah tahu bahwa Bloomka 
adalah brand yang aware dan care terhadap lingkungan, mereka tetap mengeluhkan bau yang ditimbulkan oleh product tersebut padahal bau tersebut adalah bukti bahwa product Bloomka tidak menggunakan fragrance sama sekali, beberapa keluhan yang di dapat dari konsumen yaitu data ditampilkan sebagai berikut:

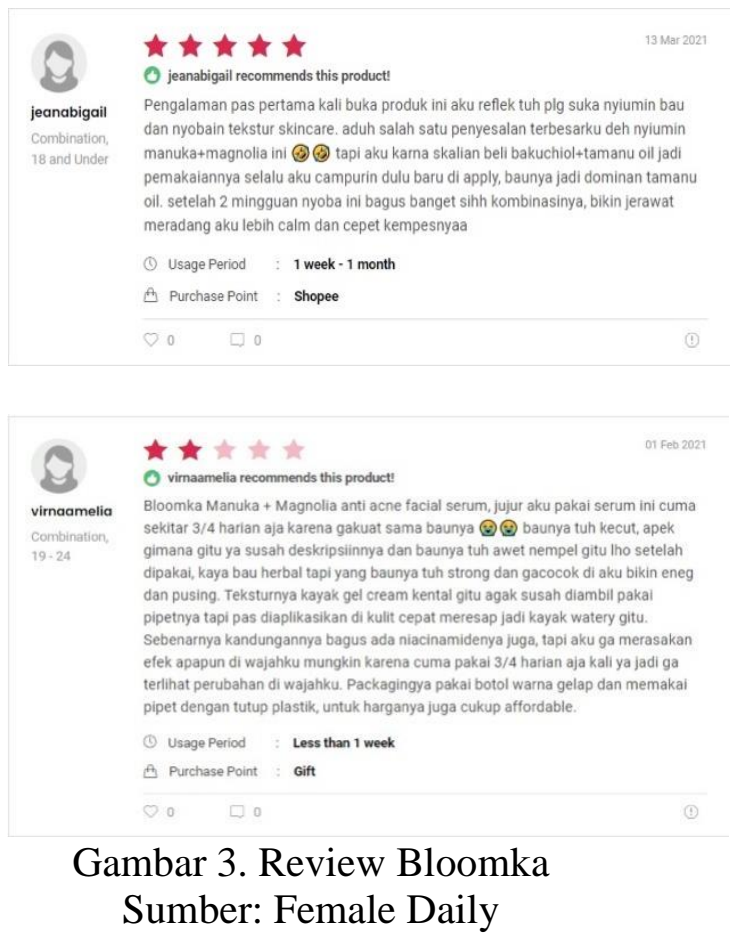

Dari review yang didapat diatas, konsumen menyatakan bahwa product Bloomka memiliki bau yang sangat menyengat dan menganggu mereka bahkan ada konsumen yang memberhentikan penggunaan product karena bau yang dimiliki productnya, tetapi mereka juga aware bahwa itu bukti product Bloomka tidak menggunakan fragrance. Konsumen juga puas dengan product karena memiliki hasil yang positif terhadap kulit mereka. Bloomka merupakan brand yang mengangkat konsep Green Marketing. Green marketing telah berkembang menjadi tren baru untuk bisnis yang mempromosikannya guna menciptakan produk sekaligus melestarikan lingkunga hidup. Selain itu, masyarakat pada dasarnya memandang bahwa green marketing lebih kearah karakteristik lingkungan untuk mengiklankan dan mempromosikan produk dan layanan. Green marketing terdiri dari banyak aktivitas yang perlu dilakukan dengan inovasi dan perubahan, perubahan dalam proses produksi yang mencakup pemilihan bahan baku, proses produksi, perbaikan dan penambahan pengemasan dan meningkatkan strategi promosi. (N.A.S.A Sabri, N. Mansor, 2020). Menurut Rambalak Yadav and Govind S. Pathak, pemasaran hijau merupakan kegiatan pemasar yang menomor satukan lingkungan yang berisi semua aktivitas guna memenuhi kebutuhan dan keinginan manusia serta meyakinkan bahwa lingkungan tetap terjaga.

Berdasarkan masalah-masalah yang mendasari latar belakang ini serta dukungan dari data Gap Research pada variabel green product, green price, green promotion and green place, sehingga peneliti ingin meneliti lebih dalam terkait informasi lebih lanjut dengan objek penelitian yang berbeda mengenai apakah green product, green price, green place dan gre en promotion memengaruhi kepuasan pelanggan bloomka skincare. Sehingga peneliti ingin menulis penelitian dengan judul "Pengaruh 4P Green Marketing Mix terhadap Kepuasan Pelanggan Bloomka Skincare” 


\section{Rumusan Masalah}

Berdasarkan latar belakang di atas, maka tujuan penelitian ini adalah sebagai berikut:

1. Apakah green product memiliki pengaruh terhadap kepuasan pelanggan?

2. Apakah green price memiliki pengaruh terhadap kepuasan pelanggan?

3. Apakah green promotion memliki pengaruh terhadap kepuasan pelanggan?

4. Apakah green place memiliki pengaruh terhadap kepuasan pelanggan?

\section{METODE PENELITIAN}

\section{Pemasaran}

Menurut Hery (2019 hlm. 3) pemasaran memiliki hubungan lekat dengan bagaimana mengenali dan memenuhi keperluan manusia dalam bermasyarakat. Salah satu definisi dari pemasaran terpendek yaitu memenuhi berbagai keperluan dengan mendapat keuntungan. Dengan kemampuan pemasaran yang cerdas, dapat mengubah keperluan pribadi maupun social menjadi suatu peluang bisnis yang mampu menghasilkan keuntungan.

Asosiasi Pemasaran Amerika memberikan pernyataan bahwa pemasaran yakni suatu organ organisasi dan sejumlah proses untuk mewujudkan, mensosialisasikan, dan memberi value kepada pelanggan, serta menata kepentingan pelanggan melalui cara dengan memberi keuntungan pada organisasi dan pemegang saham.

Menurut Hunt, konseptual pemasaran mencakup beberapa aspek seperti micro marketing dan macro marketing, positive theory of marketing dan normative theory of marketing, serta profit marketing dan non-for-profit marketing.

\section{Perilaku Konsumen}

Menurut Firmansyah (2018), perilaku konsumen dapat dedifinisikan sebagai sebuah proses yang memiliki hubungan erat dalam proses pembelian, yang meliputi berbagai aktivitas berupa penelusuran, penelitian dan penilaian sebuah produk dan jasa. Perilaku konsumen dinyatakan sebagai alasan yang melandaskan konsumen dalam membuat keputusan untuk membeli produk. (Peter, 2013) menyatakan bahwa dorongan interaksi antara bagaimana awarenress, perilaku, dan lingkungan tempat manusia melakukan hubungan terhadap aspek dalam kehidupan merupakan definisi dari perilaku konsumen

Menurut Sangadji \& Sopiah (2013), "Perilaku konsumen adalah berbagai kegiatan, aksi, serta psikologi yang mengadakan tindakan tersebut ketika sebelum membeli, Ketika membeli, menggunakan, menghabiskan produk dan jasa setelah melakukan hal-hal atau kegiatan mengevaluasi."Basu (2010) menyatakan bahwa perilaku konsumen merupakan perilaku yang mempengaruhi sikap pembeli terhadap keputusan yang akan diambil terhadap suatu produk berdasarkan pengalaman dan manfaat dari produk tersebut. Perilaku konsumen merupakan suatu tindakan, proses dan kegiatan sosial yang dilaksanakan untuk mendapatkan dan menggunakan suatu produk atau jasa karena adanya pengalaman dengan produk atau jasa tersebut.

Perilaku konsumen adalah kegiatan yang terkonsentrasi pada bagiamana individu dalam memutuskan untuk menggunakan sumber daya yang tersedia untuk mendapatkan entitas yang mereka inginkan dan dengan kegiatankonsumsi. Studi mengenai perilakukkonsumen selaku disiplin pemasaran yang independen muncul ketika pihak pemasar memahami bahwa pihak konsumenm emberikan aksi tidak selalu seperti yang dinyatakan oleh teori pemasaran.

\section{Kepuasan Pelanggan}

Suatu parameter atas baik atau buruknya suatu produk untuk dapat mencapai harapan pelanggan merupakan definisi dari kepuasan pelanggan. Harapan dibentuk setelah dilakukan pembeliannya dan menjadi acuan kepuasan sebelum mencapai loyalitas pelanggan Fikri et al. (2020). Kepuasan 
pelanggan dapat dilihat berdasarkan tingkat kualitas dan layanan suatu produk yang diberikan oleh perusahaan melalui ulasan yang mereka tulis baik directly maupun indirectly. Segala hal yang dapat mempengaruhi kepuasan pelanggan meliputi kulitas produk, nilai produk, harga yang ditawarkan dan faktor individu lainnya (Noviana, 2013)

Kepuasan dapat digambarkan dengan perasaan emosional seperti senang, sedih atau kecewa yang diperoleh setelah mendapatkan produk atau layanan yang telah diterima. Jika produk atau layanan rendah dari ekspektasi maka pelanggan tidak puas, begitupun sebaliknya, jika produk atau layanan sesuai espektasi maka pelanggan puas. Konsep kepuasan pelanggan secara lebih sistematis ditunjukan oleh gambar berikut

\section{Green Marketing}

Menurut Kotler dan Amstrong (2018), alat bauran pemasaran dikelompokan menjadi empat kategori yang biasa disebut 4P Marketing Mix diantaranya adalah produk, harga, tempat dan promosi. Sebagaimana fungsi mereka masing-masing untuk memenuhi proporsi nilainya. Pertama-tama perusahaan harus membuat produk yang dapat memenuhi kebutuhan (produk). Selanjutnya dapat memutuskan berapa banyak biaya yang digunakan untuk produk tersebut (harga) dan bagaimana menyediakan tempat untuk target konsumen(tempat) dan akhirnya, perusahaan harus menyediakan penawaran untuk meyakinkan komsumen (promosi)

Menurut Suryawardani \& Wulandari (2019), Green marketing merupakan strategi yang dipakai perusahaan dengan memanfaatkan lingkungan sebaik mungkin sehingga menciptakan suatu produk untuk meningkatkan nilai penjualan. Dari strategi ini lah konsumen akan sadar dan memiliki awareness untuk menjaga kelestarian lingkungan, dampaknya permintaan atas green product meningkat karena konsumen rela membayar lebih untuk ikut serta dalam melestarikan lingkungan. Penerapan strategi ini dinamakan green marketing mix. Green marketing mix adalah bentuk Kerjasama antara green product dengan green price atau saluran distribusi dan promosi. Hashem and Al-Rifai, n.d (2011)

\section{Green Product}

Pamungkas et al. (2015) mendefiniskan bahwa product yang aman untuk manusia dan lingkungan, hemat sumber daya, meminimalisir sampah dan tidak merusak kehidupan binatang. Produk yang dibuat sedemikian rupa untuk meminimalisir dampak pencemaran lingkungan dalam produksi, distribusi maupun konsumsi.

Menurut Pankaj dan Vishal (2014) "green product memberikan pilihan alternatif untuk menggunakan bahan organik, penghematan energi, menghilangkan produk berbahaya serta meminimalisir polusi dan limbah."berdasarkan pernyataan yang dikeluarkan tersebut maka dapat digaris bawahi bahwa green product merupakan porduk yang baik untuk penggunanya dan lingkungannya.

Produk yang diciptakan dengan bahan yang aman terhadap lingkungan, mengurangi dampak buruk terhadap lingkungan, produk serta kemasan produk dapat didaur ulang serta mampu menjaga kelestarian alam merupakan definisi dari green product (Diglel, 2014). Sedangkan green product menurut (Erciş \& Çat, 2016) adalah bukan produk yang mencemari lingkungan atau menguras sumber daya alam dan dapat dipertahankan nilainya atau didaur ulang. Diharapkan untuk tidak mengancam kesehatan manusia atau hewan, menyebabkan kerusakan lingkungan selama proses produksi, mengonsumsi energi atau sumber lain dalam jumlah yang tidak proporsional selama proses produksi, menyeba bkan limbah yang tidak perlu karena pengmasan yang berlebihan atau karena manfaat yang singkat, menyertakan penggunaan yang tidak diperlukan atau kekejaman terhadap hewan, dan menggunakan bahan dari spesies atau lingkungan yang terancam 


\section{Green Price}

Green price merupakan bagian penting dari Green Marketing Mix. Jika terdapat nilai persepsi terhadap produk, pelanggan akan menyanggupi kegiatan pembelian karena nilai tersebut merupakan peningkatan dari kinerja produk, fungsi dan daya tarik terhadap produk tersebut. Utilitas dari lingkungan dianggap bonus tetapi menjadi salah satu faktor penentu antara produk kita dengan pesaing. Kotler and Keller (2016) juga menyatakan bahwa nilai dari persepsi tersebut ada karena adanya peningkatan pada biaya, nilai dan fungsi secara rasa dan visual.

Vostac et al. (2014) memberi pernyataan lebih lanjut bahwa manfaat yang dihasilkan dari green product lebih besar daripada harganya sehingga konsumen sanggup untuk membayar lebih. Harga menurut Sharaf (2018) telah didefinisikan sebagai biaya dalam ekonomi tradisional, namun studi terbaru mengakui bahwa harga berfungsi untuk menginformasikan orangorang tentang nilai barang atau jasa. Menurut Ramli \& Fahrurrazi (2013) mendefinisikan nilai relative yang dimiliki oleh produk merupakan harga.

Menurut Akter (2012) hasil survey mengatakan bahwa konsumen sanggup untuk membeli produk dengan harga lebih mahal untuk green product yang mereka beli karena green product mempresentasikan bahwa produk ramah lingkungan mempunyai harga yang lebih mahal, tapi terdapat beberapa perbedaan antara tujuan dan kenyataan yang dilkaukan oleh konsumen yang akhirnya mengakibatkan mereka tidak jadi membeli green product tersebut. Hal ini yang menjadi evaluasi para pemasar untuk menemukan strategi yang efektif. Green price adalah penetapan harga premium dari produk yang didasari oleh kemampuan teknologi yang semakin canggih dalam menciptakan produk berbasis lingkungan.

\section{Green Place}

Daya tarik signifikan yang dapat memicu pelanggan berdasarkan opsi dimana dan kapan produk tersedia. Tidak banyak pelanggan yang tertarik untuk membeli green product. Promosi dapat dilakukan di lokasi penjualan, maka dari itu lokasi harus sesuai dengan rencana yang diinginkan perusahaan dan lokasi harus dapat menjadi pembeda antara perusahaan dengan pesaing. Lokasi juga didesign secara visual atau dengan menggunakan bahan-bahan daur ulang untuk menarik konsumen.

Kontic (2010) menyatakan bahwa melebihi dari rata-rata, pelanggan tidak mau pergi jauh untuk mendapatkan green product dan cenderung akan memilih alternatif yang lebih dekat, nyatanya lokasi dan akses memiliki pengaruh pada pelanggan

Lokasi sebagai tempat untuk memproyeksikan produk yang sudah melewati proses produksi untuk konsumen. Salah satu tugas dari distribusi yakni memilih penguhubung antara saluran dalam distribusi yang secara fisik mengantarkan produk menuju pasar sasaran. Kusnandar (2017)

Distribusi hijau merupakan suatu system bagaimana logistic bisa mencapai kepada konsumen dengan meminimalisir pengiriman barang dengan jarak jauh sehingga dapat mengecilkan biaya pengiriman serta emisi karbon. (Savitri, 2016), "the choice of where and when to make a product available will have significant impact on the customers." Salah satu hal yang sangat berdampak pada pelanggan adalah pilihan posisi dimana dan kapan produk dpaat terjangkau.

\section{Green Promotion}

Target pasar dapat dituju melalui promosi produk dan layanan seperti hubungan dengan masyarakat, mengadakan promosi pembelian, pemasaran yang dilakukan secara langsung di tempat. Pemasar green product yang cerdas akan menjaga lingkungan dengan menggunakan kegiatan pemasaran yang berkelanjutan karena kunci keberhasilan dalam bauran pemasaran hijau adalah kredibilitas. 
Agyeman (2014) menyatakan bahwa opsi yang dimiliki konsumen terhadap green product memiliki peluang yang tinggi dipicu oleh packagingnya. Govender \& Govender (2016) memberikan pendapat bahwa kebanyakan wanita sebagai konsumen akan melakukan pengecekan terhadap green product untuk memastikan apakah produk tersebut benar adanya untuk dapat dikatakan sebagai green product.

Hasan (2015) mengatakan green promotion adalah sarana yang efektif untuk mempromosikan produk, jasa/layanan, ide dan upaya perusahaan untuk menunjukka nkepedulian dan inisiatif mereka untuk melindungi dan melestarikan lingkungan. Hal ini $\mathrm{j}$ uga dijadikan peluang yang dipakai perusahaan untuk berbagi dan menginformasikan pera $\mathrm{n}$ bahwa perusahaan juga berdampak langsung dengan masalah global, sejalan dengan kes adaran yang diperlihatkan oleh masyarakat.

Komunikasi yang bertujuan untuk memberikan pengetahuan seputar produk kepada konsumen yang dapat memuaskan kebutuhan sehingga konsumen memiliki tendensi untuk membeli adalah definisi dari promosi (Buchari, 2014). Green promotion memberikan informasi aktual terkait produk yang diproduksi dengan tidak menganggu kenyamanan konsumen. Perilaku yang dihasilkan konsumen dalam melakukan pembelian dapat dipicu oleh psikologi. Dimaksudkan dengan melakukan pembelian ini akan memenuhi kebutuhan konsumen secra fungsional, social dan psikologisnya (Siswanto, 2011). Terdapat empat faktor yang mendukung bauran promosi yaitu periklanan, penjualan secara pribadi dan promosi di public.

\section{Teknik Analisis Deskriptif}

Pada penelitian ini peneliti menggunakan teknik analisis data deskriptif atau statistic deskriptif. Analisis data deskriptif merupakan statistic yang menggambarkan karakteristik atau fenomena dari data yang telah dikumpulkan oleh peneliti tanpa adanya kesimpulan y ang berlaku untuk digeneralisasikan. (Wiyono, $2020 \mathrm{hlm}$. 180). Data tersebut diperoleh dari jawaban yang diberikan kepada responden terhadap item yang terdapat dalam kuesio ner yang berikan oleh peneliti. Analisis deskriptif dalam penelitian ini dilakukan dengan menggunakan output PLS berdasarkan hasil pengolahan mean, min, max dan standar deviasi. Nilai standar deviasi harus lebih kecil dari nilai mean yang menunjukan bahwa tidak ada kesenjangan atau variasi data yang cukup besar dari variabel yang ingin diukur. Nilai minimum digunakan untuk melihat nilai yang terbesar pada masing-masing variabel dalam penelitian ini. Nilai mean adalah nilai rata-rata atas sekumpulan data variabel-variabel dalam penelitian. Selain itu, nilai standar deviasi dalam penelitian ini digunakan untuk melihat tinggi rendahnya penyimpangan atau variasi suatu data. Sehingga variabel dalam penelitian ini adalah green product, green price, green place dan green promotion sebagai variabel independent, sedangkan variabel dependen dalam penelitian ini yaitu kepuasan pelanggan. (Dimas Ifanda Putra Kusuma, 2020)

\section{Teknik Analisis Data Inferensia}

Menurut Sutopo \& Slamet (2017, hlm. 2) analisis inferensial adalah analisis data yang dipakai penelitian untuk mengetahui data pada sampel sertakhasil yang diperolehkakan dis impulkan melalui sampel yang diambil. Analisis inferensial yang dilakukan pada penelitian ini diperoleh melalui output Partial Least Squaare (PLS), yaitu metode analisis yang powerful atau

biasa disebut sebagai soft modelling karena tidak didasarkan banyak asumsi, data tidak ha rus berdistribusi normal multivariate, sampel yang digunakan tidak harus besar dan dapat digunakan untuk menjelaskan hubungan variabel laten. (Ghozali, $2015 \mathrm{hlm}$. 5). Menurut Noor (2014, hlm. 146) terdapat beberapa langkah dalam menggunakan software Smart PLS yaitu sebagai berikut: 


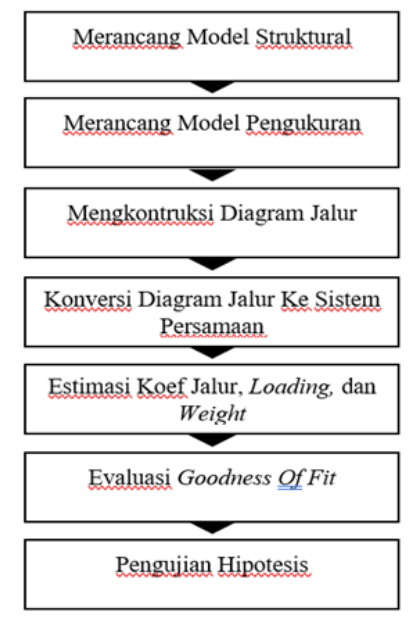

\section{Uji Validitas}

Gambar 4. Tahapan penggunaan Software PLS

(Ferdinand, 2018, hlm.217) mengatakan "validitas dapat diartikan sebagai alat uji yang dimaksudkan untuk melakukan pengukuran atas apa yang seharusnya di ukur. Uji validitas merupakan pengukuran alat yang digunakan untuk memberikan kepastian instrumen yang digunakan dapat mengukur suatu variabel secara valid". Menurut (Sugiyono, 2019 hlm.175) "hasil dari suatu penelitian dinyatakan valid apabila memiliki persamaan antara data yang didapatkan dengan data sebenarnya yang terjadi pada objek yang diteliti”. Suatu instrument yang telah dinyatakan valid artinya memiliki alat ukur yang tepat sehingga dapat memperoleh data valid, hal tersebut dikarenakan instrument tersebut bisa digunakan untuk mengukur apa yang seharusnya di ukur.

Uji validitas model indikator reflektif, dapat dilakukan dengan menganalisis convergent validity, dan discriminant validity. Dari uji convergent validity, loading factor serta AVE senilai 0,50 hingga 0,60 dinyatakan sudah cukup, sedangkan berdasarkan uji discriminant validity, terdapat saran nilai akar AVE harus diatas 0,50.

\section{Uji Reliabilitas}

"Uji realibilitas merupakan alat untuk mengukur suatu kuisioner yang merupakan indikator dari variabel atau konstruk. Suatu kuisioner dikatakan reliabel atau handal jika jawaban responden terhadap pernyataan adalah konsisten atau stabil dari waktu ke waktu (Ghozali, 2018 hlm. 45)". Dengan digunakannya PLS dalam penelitian ini, maka dapat diketahui bahwa reliabilitas suatu item dapat diketahui dengan menggunakan construct reliability atau CR sebesar $\geq 0.6$ maka item dapat dikatakan reliabel.

Uji reliabilitas pada model indikator reflektif dapat dilakukan dengan dua kriteria, yaitu dengan menggunakan composite reliability dan cronbach's alpha (Ghozali, 2014 hlm.65). Sehingga konstruk dapat dikatakan reliabel jika nilai cronbach's alpha dan composite reliability diatas 0,60 . Berikut kriteria reliabilitas berdasarkan nilai alpha.

Tabel 1. Kriteria Reliabilitas

\begin{tabular}{cc}
\hline Alpha & Tingkat reliabilitas \\
\hline $0,0-0,2$ & Kurang reliabel \\
\hline $0,2-0,4$ & Agak reliabel \\
\hline $0,4-0,6$ & Cukup reliabel \\
\hline $0,6-0,8$ & Reliabel \\
\hline $0,8-1,0$ & Sangat reliabel \\
\hline
\end{tabular}




\section{Uji $\mathbf{R}^{2}$ (Koefisien Determinasi)}

"Analisis koefesien determinasi $\left(\mathrm{R}^{2}\right)$ berfungsi guna mengukur seberapa jauh kemampuan model dalam menerangkan variasi model dalam menerangkan variasi variabel dependen. Nilai koefisien determinasi $\left(\mathrm{R}^{2}\right.$ ) besarnya antara 0 (nol) dan 1 (satu). Nilai $\mathrm{R}^{2}$ yang kecil berarti kemampuan variabel - variabel independen dalam menjelaskan variasi variabel dependen amat terbatas. Nilai yang mendekati satu berarti variabel - variabel independen memberikan hampir semua informasi yang dibutuhkan untuk memprediksi variasi variabel dependen. Jika $\mathrm{R}^{2}$ sama dengan 1 , maka variabel independen berpengaruh secara sempurna terhadap variabel dependen" (Ghozali, 2016 hlm. 95)

\section{Uji T}

"Uji statistik t pada dasarnya menunjukkan seberapa jauh pengaruh satu variabel penjelas atau independen secara individual dalam menerangkan variasi variabel dependen" (Ghozali, $2016 \mathrm{hlm}$ 97).

Hipotesis nol $\left(\mathrm{H}_{0}\right)$ yang akan dilakukan pengujian adalah apakah suatu parameter (bi) sama dengan nol, atau:

Hipotesis 1 : Citra merek berpengaruh terhadap keputusan pembelian pada Indomie Uji hipotesis tersebut dapat diasumsikan sebagai berikut :

$\mathrm{H}_{0}=$ Citra merek $\left(\mathrm{X}_{1}\right)$ tidak berpengaruh terhadap keputusan pembelian Indomie

$\mathrm{H}_{1}=$ Citra merek $\left(\mathrm{X}_{1}\right)$ berpengaruh terhadap keputusan pembelian Indomie

Hipotesis 2 : Kualitas produk berpengaruh terhadap keputusan pembelian pada Indomie

Uji hipotesis tersebut dapat diasumsikan sebagai berikut :

$\mathrm{H}_{0}=$ Kualitas produk $\left(\mathrm{X}_{2}\right)$ tidak berpengaruh terhadap keputusan pembelian Indomie

$\mathrm{H}_{2}=$ Kualitas produk $\left(\mathrm{X}_{2}\right)$ berpengaruh terhadap keputusan pembelian Indomie

Dasar pengambilan uji hipotesis dalam penelitian yaitu jika nilai tTabel > thitung maka Ho diterima dan $\mathrm{Ha}$ ditolak, maka dapat diketahui bahwa variabel independent tidak memiliki pengaruh pada variabel dependen. Tetapi bila nilai t tabel < thitung atau maka Ho ditolak dan Ha diterima, sehingga dapat diketahui bahwa variabel independent berpengaruh terhadap variabel dependen

\section{HASIL DAN PEMBAHASAN}

\section{Deskripsi Data}

Responden pada penelitian ini yaitu masyarakat yang pernah menggunakan skincare Bloomka dan berdomisili di DKI Jakarta. Penulis mengambil 100 responden yang sesuai dengan kriteria yang digunakan untuk menguji data pada penelitian yaitu berusia antara 17-25 tahun dan pernah menggunakan product Bloomka. Adapun karakteristik responden pada penelitian ini yaitu jenis kelamin, usia, pekerjaan, dan domisili kotamadya

a. Kakteristik Responden Menurut Jenis Kelamin

Berdasarkan hasil penyebaran kuesioner diperolah diagram untuk karakteristik responden menurut jenis kelamin yaitu sebagai berikut: 


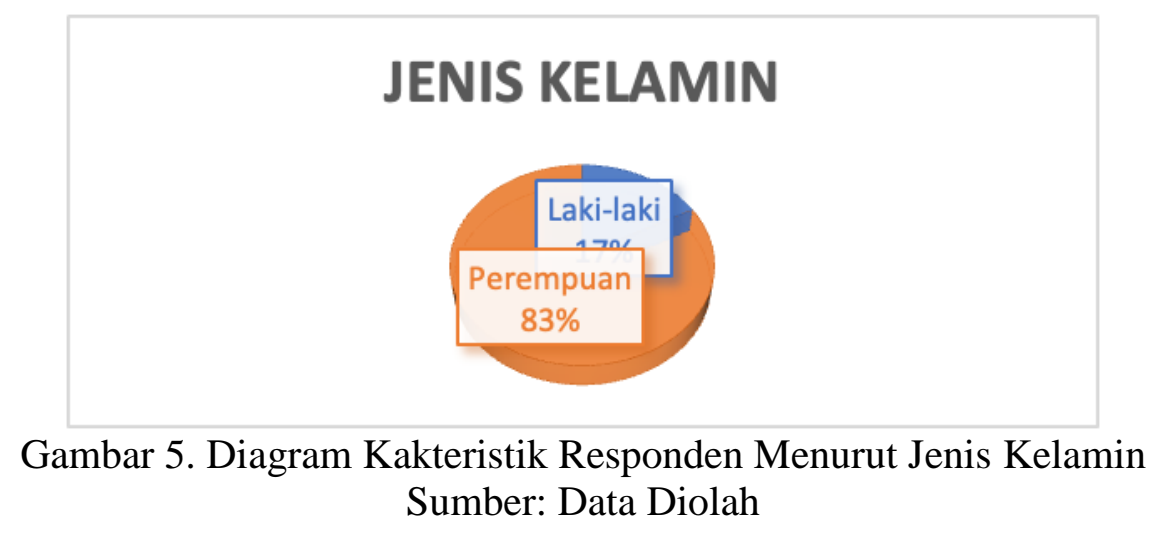

Pada gambar dapat disimpulkan bahwa jumlah responden yang berjenis kelamin perempuan sebanyak 83 orang atau $83 \%$ sedangkan jumlah responden yang berjenis kelamin laki-laki sebanyak 17 orang atau 17\%. Sehingga dapat disimpulkan responden yang pernah dan atau sedang menggunakan produk Bloomka didominasi oleh perempuan. Pernyataan ini didukung oleh artikel yang ditulis Global Business Guide yang menyatakan bahwa di Indonesia, pertumbuhan volume penjualan industri kosmetik didongkrak oleh permintaan yang meninggi dari kelas menengah. Populasi perempuan Indonesia sebagai pengguna kosmetik kini telah mencapai 126,8 juta orang

\section{b. Karakteristik Responden Menurut Usia}

Berdasarkan hasil penyebaran kuesioner diperoleh diagram untuk karakteristik responden menurut usia yaitu seebagai berikut:

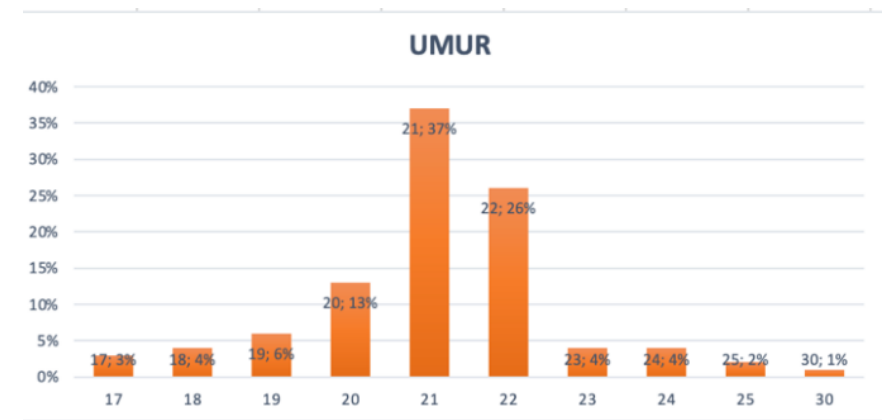

Gambar 6. Diagram Kakteristik Responden Menurut Usia Sumber: Data Diolah

Berdasarkan gambar dapat disimpulkan bahwa jumlah responden pada penelitian ini yaitu usia 17 tahun sebanyak 3 orang atau 3\%, usia 18 tahun sebanyak 4 atau 4\%, usia 19 tahun sebanyak 6 orang atau $6 \%$, usia 20 sebanyak 13 orang atau 13\%, usia 21 tahun sebanyak 37 orang atau $37 \%$, usia 22 tahun sebanyak 26 orang atau 26\%, usia 23 sebanyak 4 orang atau $4 \%$, usia 24 sebanyak 4 orang atau 4\%, usia 25 sebanyak 2 orang atau 2\% dan usia 30 tahun sebanyak 1 orang atau $1 \%$ sehingga dapat dinyatakan bahwa kategori responden pelanggan bloomka berusia 21 tahun lebih mendominasi. Pernyataan ini didukung oleh penelitian yang dilakukan oleh Yasanova Savitry (2020), 45,4\% perempuan di Indonesia menggunakan skincare atau produk perawatan kulit sebelum usia 19 tahun. Data juga menunjukkan satu dari empat perempuan merawat diri di klinik kecantikan sebelum berusia 19 tahun. Gen $\mathrm{Z}$ menggunakan hampir seluruh pendapatan yang 


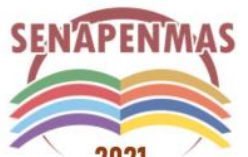

2021
Seminar Nasional Hasil Penelitian dan Pengabdian Kepada Masyarakat 2021

Pengembangan Ekonomi Bangsa Melalui Inovasi Digital Hasil Penelitian dan Pengabdian Kepada Masyarakat Jakarta, 21 Oktober 2021

mereka punya untuk perawatan kecantikan. Sementara Gen Y hanya menggunakan 30 persen dan Gen X justru kurang dari 5 persen

c. Karakteristik Responden Menurut Pekerjaan

Berdasarkan hasil penyebaran kuesioner diperoleh diagram untuk karakteristik responden menurut pekerjaan sebagai berikut:

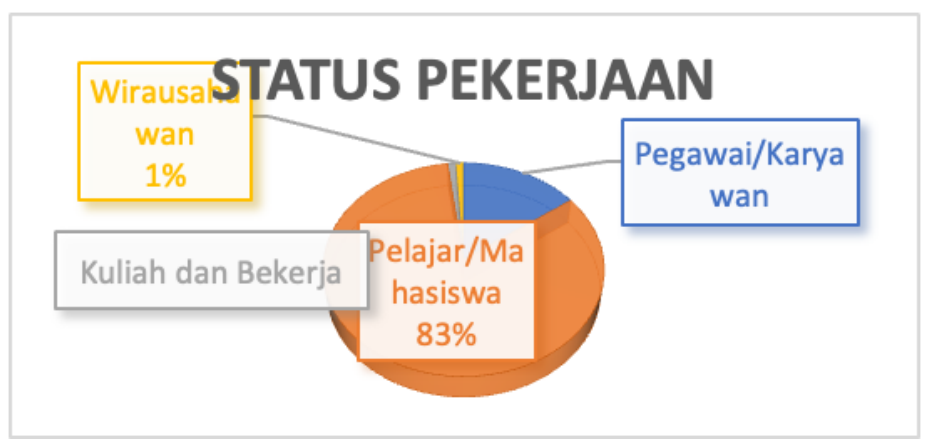

Gambar 7. Diagram Kakteristik Responden Menurut Pekerjaan

Sumber: Data Diolah

Berdasarkan gambar dijelaskan bahwa jumlah responden berdasarkan pekerjaan dibagi menjadi pelajar/mahasiswa sebanyak 83 orang atau 83\%, pegawai/karyawan sebanyak 15 orang atau $15 \%$, kuliah dan bekerja sebanyak satu orang atau $1 \%$ dan wirausahawan sebanyak satu orang atau $1 \%$ sehingga dapat disimpulkan bahwa pelanggan bloomka pada penelitian ini mayoritas merupakan pelajar atau mahasiswa yakni sebanyak 83 orang atau $83 \%$. Hal ini terjadi karena berdasarkan kuesioner diatas didominasi oleh pelajar atau mahasiswa karena target audience yang ditetapkan oleh bloomka adalah remaja

d. Karakteristik Responden Menurut Pendidikan Terakhir

Berdasarkan hasil penyebaran kuesioner diperoleh diagram untuk karakteristik responden menurut Pendidikan terakhir nya adalah sebagai berikut:

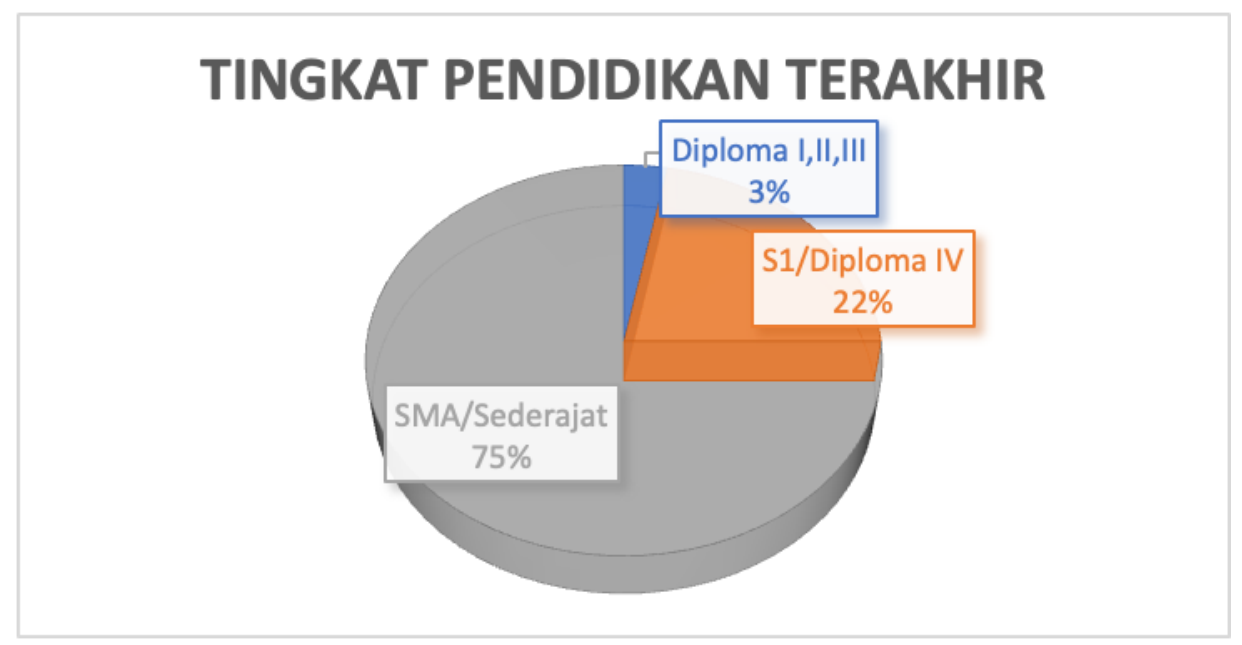

Gambar 8. Diagram Kakteristik Responden Menurut Pendidikan Terakhir Sumber: Data Diolah

Berdasarkan gambar dapat disimpulkan bahwa jumlah responden berdasarkan Pendidikan terakhir dikelompokan menjadi SMA/Sederajat sebanyak 75 orang atau 75\%, Diploma I,II,III sebanyak 3 orang atau 3\%, dan S1/Diploma IV sebanyak 22 orang atau 22\% sehingga dapat 
ditarik kesimpulan bahwa pelanggan bloomka dalam penelitian ini mayoritas Pendidikan terakhirnya adalah SMA/Sederajat karena target audience dari bloomka merupakan remaja. Hal ini juga sejalan dengan penelitian yang dilakukan Andreas Kevin (2018), yang berpendapat bahwa perubahan pada lifestyle yang disebabkan karena faktor awareness terhadap lingkungan, tren saat ini, dan tingginya cakupan informasi Pendidikan maupun kesehatan mengantarkan konsumen meminta akan visibilitas produk yang mereka beli. Mereka akan menyelidiki terkait ptoduk tersebut.

e. Karakteristik Responden Menurut Penghasilan Perbulan

Berdasarkan hasil penyebaran kuesioner diperoleh diagram untuk karakteristik responden menurut pendapatan perbulan nya adalah sebagai berikut:

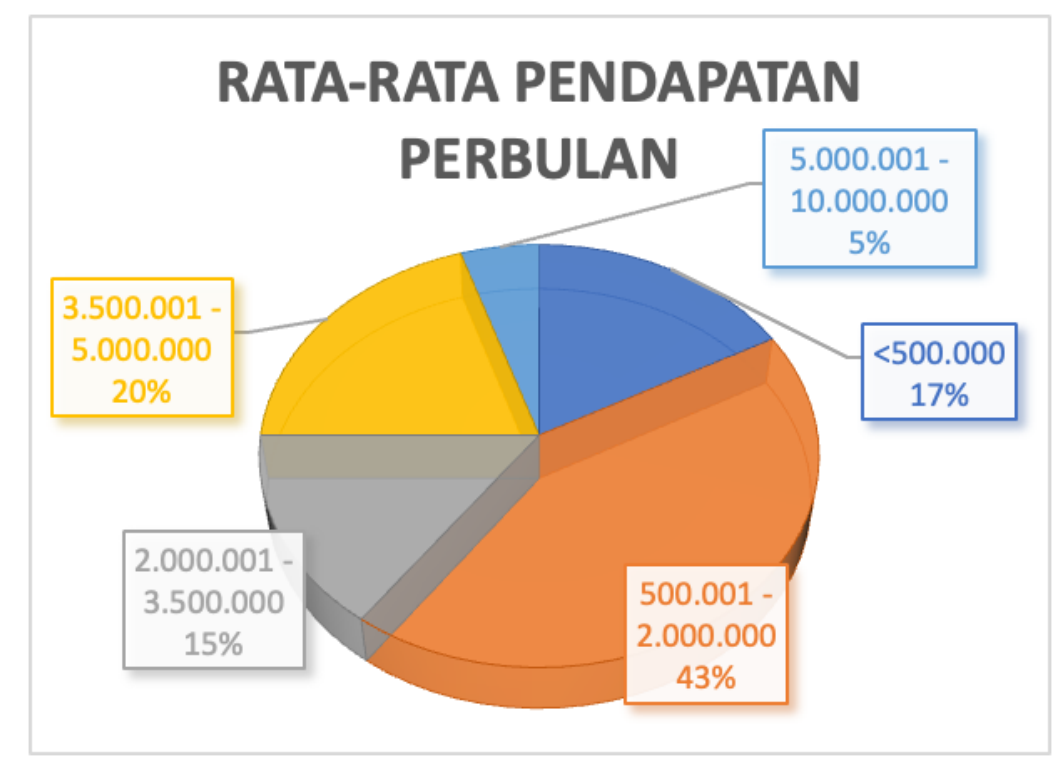

Gambar 9. Diagram Kakteristik Responden Menurut Pendidikan Terakhir Sumber: Data Diolah

Berdasarkan gambar dapat disimpulkan bahwa jumlah responden berdasarkan pendapat perbulannya dikelompokkan menjadi 5 kategori yaitu pendapatan kurang dari 500.000 sebanyak 17 orang atau $17 \%, 500.001-2.000 .000$ sebanyak 43 orang atau 43\%, $2.000 .001-3.500 .000$ sebanyak 15 orang atau 15\%, 3.500.001 - 5.000.000 sebanyak 20 orang atau 20\%, 5.000.00110.000.000 sebanyak 5 orang atau 5\% sehingga dapat disimpulkan bahwa pelanggan bloomka pada penelitian ini mayoritas memiliki pendapatan sebanyak 500.001-2.000.000. Hal ini dikarenakan pelanggan bloomka pada penelitian ini didominasi oleh pelajar atau mahasiswa seperti yang tertera pada gambar (pekerjaan) yang dimana mereka belum memiliki penghasilan tetap.

f. Karakteristik Responden Menurut Pengeluaran Perbulan

Berdasarkan hasil penyebaran kuesioner diperoleh diagram untuk karakteristik responden menurut pengeluaran perbulan nya adalah sebagai berikut: 


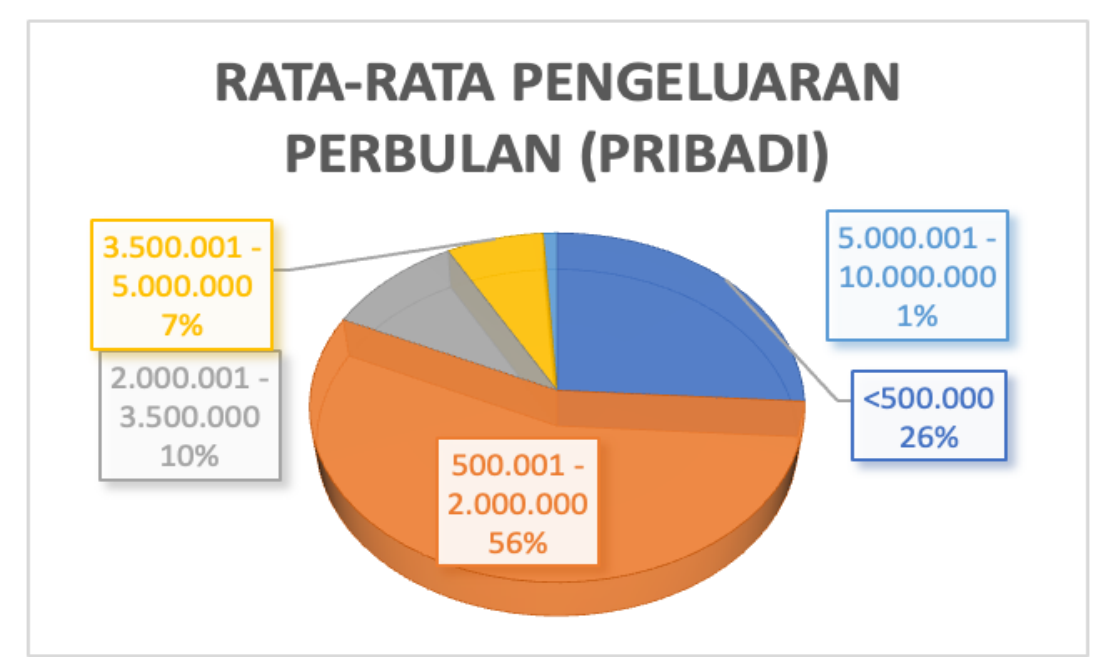

Gambar 10. Diagram Kakteristik Responden Menurut Pengeluaran Perbulan Sumber: Data Diolah

Berdasarkan gambar dapat disimpulkan bahwa jumlah responden berdasarkan pendapat perbulannya dikelompokkan menjadi 5 kategori yaitu pendapatan kurang dari 500.000 sebanyak 26 orang atau $26 \%, 500.001-2.000 .000$ sebanyak 56 orang atau $56 \%, 2.000 .001-3.500 .000$ sebanyak 10 orang atau $10 \%, 3.500 .001-5.000 .000$ sebanyak 7 orang atau 7\%, 5.000.00110.000.000 sebanyak 1 orang atau $1 \%$ sehingga dapat dinyatakan bahwa mayoritas pelanggan bloomka memiliki pengeluaran sebanyak 500.001-2.000.000. Hal ini sejalan dengan penelitian yang dilakukan oleh Wifka Rahma Syauki (2020) Mayoritas sebanyak 44,1\% perempuan milenial menetapkan anggaran sebesar 100.000 - 500.000 untuk membeli skincare

g. Karakteristik Responden Menurut Domisili Kotamadya

Berdasarkan hasil penyebaran kuesioner diperoleh diagram untuk karakteristik responden menurut domisili nya adalah sebagai berikut:

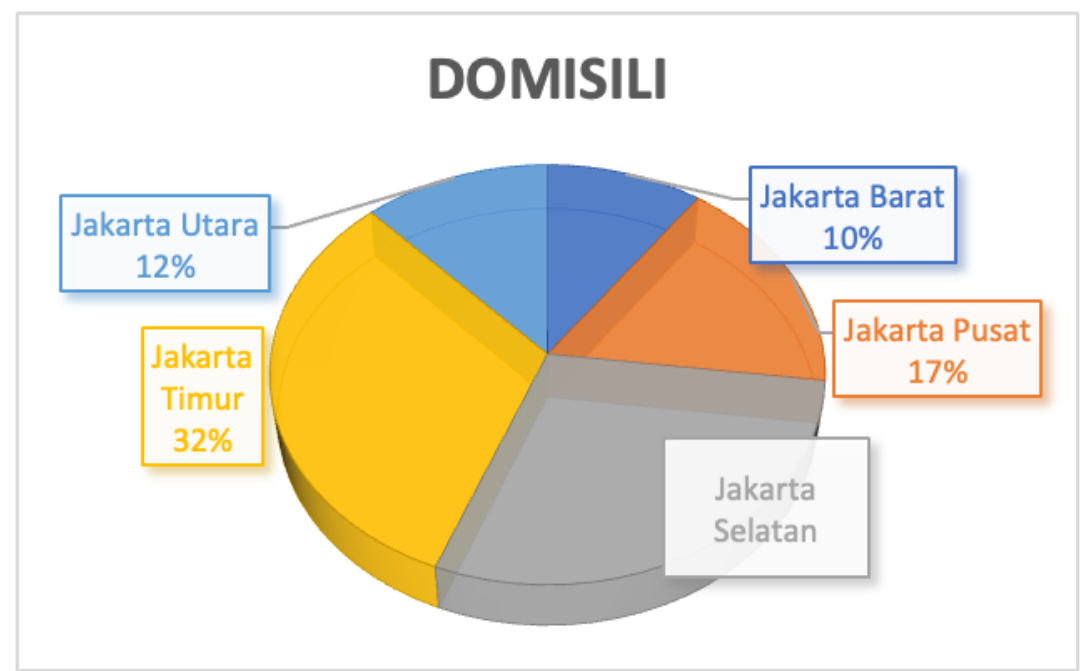

Gambar 11. Diagram Kakteristik Responden Menurut Pengeluaran Perbulan Sumber: Data Diolah

Berdasarkan gambar dapat disimpulkan bahwa jumlah responden berdasarkan domisili dikelompokkan menjadi 5 kategori yaitu Jakarta Barat sebanyak 10 orang atau 10\%, Jakarta Pusat sebanyak 17 orang atau 17\%, Jakarta Selatan sebanyak 29 orang atau 29\%, Jakarta Timur 
sebanyak 32 orang atau 32\%, Jakarta Utara sebanyak 12 orang atau $12 \%$ sehingga dapat dinyatakan bahwa mayoritas pelanggan bloomka pada penelitian ini mayoritas berdomisili di Jakarta Timur.

\section{Analisis Data Deskriptif}

Analisis data deskriptif pada penelitian ini menggunakan hasil perhitungan output SmartPLS 3.0 yaitu berdasarkan nilai mean, minimum, maximum dan standar deviasi yang dapat dilihat pada tabel dibawah ini

Tabel 2. Statistik Deskriptif Variabel Kepuasan Pelanggan

\begin{tabular}{lllll}
\hline Keputusan Penggunaan & Mean & Min & Max & Standard Deviation \\
\hline KP1 & 4.53 & 3 & 5 & 0.373 \\
\hline KP2 & 4.57 & 3 & 5 & 0.419 \\
\hline KP3 & 4.36 & 3 & 5 & 0.486 \\
\hline KP4 & 4.28 & 3 & 5 & 0.491 \\
\hline KP5 & 4.27 & 3 & 5 & 0.469 \\
\hline KP6 & 4.33 & 3 & 5 & 0.511 \\
\hline KP8 & 4.45 & 3 & 5 & 0.443 \\
\hline
\end{tabular}

Sumber: Hasil output Smart PLS 3.0

Berdasarkan tabel penilaian responden terhadap variabel kepuasan pelanggan dapat terlihat bahwa variabel kepuasan pelanggan memiliki nilai rata-rata (mean) paling besara terdapat pada butir pernyataan KP2 dengan nilai rata-rata (mean) sebesar 4.57. Angka tersebut menunjukan rata-rata responden setuju dengan pernyataan "Harga sesuai dengan fasilitas" artinya para responden merasa bahwa fasilitas yang diberikan sesuai dengan harga. Selanjutnya nilai rata-rata (mean) terkecil pada butir pernyataan KP5. Angka tersebut menunjukan rata-rata responden setuju dengan pernyataan "Produk sudah sesuai dengan apa yang diharapkan" Artinya responden merasa produk belum sesuai dengan apa yang diharapkan. Selanjutnya, pada tabel tersebut terlihat bahwa nilai minimum setiap butir pernyataan variabel kepuasan pelanggan para responden memberikan nilai minimum skor adalah 3 dan nilai maksimum yang diberikan oleh responden dengan nilai skor 5. Nilai standar deviasi pada setiap butir pernyataan variabel kepuasan pelanggan (KP) memiliki nilai lebih kecil dari nilai rata-rata (mean) menunjukan sebaran variasi data variabel yang kecil atau tidak adanya kesenjangan penyimpangan data yang cukup besar.

Tabel 3. Statistik Deskriptif Variabel Green Product

\begin{tabular}{lllll}
\hline Green Product & Mean & Min & Max & Standard Deviation \\
\hline GP1 & 4.35 & 1 & 5 & 0,522 \\
\hline GP2 & 4.54 & 3 & 5 & 0,397 \\
\hline GP3 & 4.49 & 3 & 5 & 0,444 \\
\hline GP4 & 4.17 & 2 & 5 & 0,581 \\
\hline GP5 & 4.30 & 3 & 5 & 0,515 \\
\hline GP7 & 4.13 & 2 & 5 & 0,641 \\
\hline GP8 & 4.51 & 3 & 5 & 0,455 \\
\hline GP9 & 4.75 & 3 & 5 & 0,331 \\
\hline GP10 & 4.17 & 3 & 5 & 0,564 \\
\hline Sumber & 4.05 & 3 & 5 & 0,540
\end{tabular}

Sumber: Hasil Output Smart PLS 3.0 
Berdasarkan tabel penilaian responden terhadap variabel Green Product dapat terlihat bahwa variabel Green Product memiliki nilai rata-rata (mean) paling besar terdapat pada butir pernyataan GP2 dengan nilai rata-rata sebesar 4.54. Angka tersebut menunjukan rata-rata responden setuju dengan pernyataan "Bahan yang digunakan berbahan dasar tumbuhan" artinya para responden menggunakan product bloomka yang berbahan dasar tumbuhan. Selanjutnya nilai rata-rata (mean) terendah pada butir pernyataan GP10 dengan nilai rata-rata sebesar 4.05. Angka tersebut menunjukan rata-rata responden setuju dengan pernyataan "Daya tahan produk tidak lebih lama dari produk tidak berbahan dasar alami" yang artinya daya tahan produk lebih cepat dibanding produk yang tidak menggunakan bahan dasar alami. Selanjutnya, pada tabel tersebut terlihat bahwa nilai minimun setiap butir pernyataan variabel green product para responden memberikan dengan nilai skor 1 dan nilai maksimum yang diberikan oleh responden dengan nilai skor 5. Nilai standar deviasi pada setiap butir pernyataan variabel Green Product (GP) memiliki nilai lebih kecil dari nilai rata-rata (mean) menunjukan sebaran variasi data variabel yang kecil atau tidak adanya kesenjangan penyimpangan data yang cukup besar.

\begin{tabular}{lllll}
\multicolumn{5}{l}{ Tabel 4. Statistik Deskriptif Variabel Green Price } \\
\hline Green Price & Mean & Min & Max & Standard Deviation \\
\hline GPC1 & 4.18 & 4 & 5 & 0,55 \\
\hline GPC2 & 4.45 & 5 & 5 & 0,454 \\
\hline GPC3 & 4.38 & 4 & 5 & 0,425 \\
\hline GPC4 & 4.40 & 4 & 5 & 0,438 \\
\hline GPC5 & 4.71 & 5 & 5 & 0,344 \\
\hline GPC6 & 4.61 & 5 & 5 & 0,427 \\
\hline GPC7 & 4.44 & 5 & 5 & 0,431 \\
\hline GPC8 & 4.33 & 4 & 5 & 0,491 \\
\hline Sumber Han
\end{tabular}

Sumber: Hasil Output Smart PLS 3.0

Berdasarkan tabel penelitian responden terhadap variabel Green Price dapat terlihat bahwa variabel green price memiliki nilai rata-rata (mean) paling besar terdapat pada butir pernyataan GPC5 dengan nilai rata-rata (mean) sebesar 4,71. Angka tersebut menunjukan rata-rata responden setuju dengan pernyataan "Potongan harga yang diberikan memicu konsumen untuk membeli" yang artinya keinginan konsumen untuk membeli produk bloomka meningkat bila ada potongan harga. Selanjutnya nilai rata-rata (mean) terendah terdapat pada butir pernyataan GPC1 dengan nilai sebesar 4,18. Angka tersebut menunjukan rata-rata responden setuju dengan pernyataan "Biaya yang dikeluarkan sebanding dengan biaya melestarikan lingkungan" artinya konsumen ikut berpartisipasi menjaga lingkungan ketika membeli produk bloomka. Selanjutnya, pada tabel tersebut terlihat bahwa nilai minimum setiap butir pernyataan variabel green price para responden memberikan dengan nilai skor 4 dan nilai maksimum yang diberikan oleh responden adalah skor 5. Nilai standar deviasi pada setiap butir pernyataan variabel green price (GPC) memiliki nilai lebih kecil dari nilai rata-rata (mean) menunjukan sebaran variasi data variabel yang kecil atau tidak adanya kesenjangan penyimpangan data yang cukup besar. 
Tabel 5. Statistik Deskriptif Variabel Green Place

\begin{tabular}{lllll}
\hline Green Place & Mean & Min & Max & Standard Deviation \\
\hline GPL1 & 4.27 & 3 & 5 & 0,554 \\
\hline GPL2 & 4.45 & 3 & 5 & 0,454 \\
\hline GPL3 & 4.17 & 2 & 5 & 0,547 \\
\hline GPL5 & 4.34 & 3 & 5 & 0,472 \\
\hline GPL6 & 4.02 & 2 & 5 & 0,555 \\
\hline GPL7 & 4.27 & 2 & 5 & 0,518 \\
\hline GPL8 & 4.30 & 3 & 5 & 0,524 \\
\hline GPL9 & 4.17 & 2 & 5 & 0,529 \\
\hline GPL10 & 4.21 & 2 & 5 & 0,549 \\
\hline
\end{tabular}

\section{Sumber: Hasil Output Smart PLS 3.0}

Berdasarkan tabel penilaian responden terhadap variabel green place terlihat bahwa variabel green place memiliki nilai rata-rata (mean) paling besar terdapat pada butir pernyataan GPL2 dengan nilai rata-rata (mean) sebesar 4,45. Angka tersebut menunjukan rata-rata responden setuju dengan pernyataan "Lokasi mudah dicapai oleh konsumen" yang artinya lokasi bloomka mudah didatangi oleh konsumen. Selanjutnya dan nilai rata-rata (mean) terkecil pada butir pernyataan GPL3 dan GPL9 dengan nilai sebesar 4,17. Angka tersebut menunjukan rata-rata responden setuju dengan pernyataan "Lokasi mempresentasikan bentuk kelestarian lingkungan" dan "Lokasi memiliki lahan parkir" yang artinya toko bloomka menunjukan bentuk melestarikan alam dan toko bloomka memliki lahan parkir. Selanjutnya, pada tabel tersebut terlihat bahwa nilai minimum setiap butir pernyataan variabel green place para responden memberikan dengan nilai skor 2 dan nilai maksimum yang diberikan oleh reponden dengan nilai skor 5 . Nilai standar deviasi pada setiap butir pernyataan variabel green place (GPL) memiliki nilai lebih kecil dari nilai rata-rata (mean) menunjukan sebaran variasi data variabel yang kecil atau tidak adanya kesenjangan penyimpangan data yang cukup besar.

Tabel 6. Statistik Deskriptif Variabel Green Promotion

\begin{tabular}{lllll}
\hline Green Promotion & Mean & Min & Max & Standard Deviation \\
\hline GPO1 & 4.67 & 3 & 5 & 0,381 \\
\hline GPO2 & 4.64 & 3 & 5 & 0,386 \\
\hline GPO3 & 4.45 & 3 & 5 & 0,464 \\
\hline GPO4 & 4.42 & 3 & 5 & 0,482 \\
\hline GPO5 & 4.63 & 3 & 5 & 0,400 \\
\hline GPO6 & 4.57 & 3 & 5 & 0,407 \\
\hline GPO7 & 4.58 & 3 & 5 & 0,418 \\
\hline GPO8 & 4.65 & 3 & 5 & 0,372 \\
\hline GPO9 & 4.54 & 2 & 5 & 0,454 \\
\hline GPO10 & 4.54 & 3 & 5 & 0,421 \\
\hline \multicolumn{5}{c}{ Sumber: Hasil Output Smart PLS 3.0 }
\end{tabular}

Berdasarkan tabel penilaian responden terhadap variabel Green Promotion dapat terlihat bahwa variabel Green Promotion memiliki nilai rata-rata (mean) paling besar terdapat pada butir 


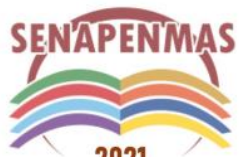

2021
Seminar Nasional Hasil Penelitian dan Pengabdian Kepada Masyarakat 2021 Pengembangan Ekonomi Bangsa Melalui Inovasi Digital Hasil Penelitian dan Pengabdian Kepada Masyarakat Jakarta, 21 Oktober 2021

pernyataan GPO1 dengan nilai sebesar 4,67. Angka tersebut menunjukan rata-rata responden setuju dengan pernyataan "Media periklanan sesuai dengan target audience" yang artinya bentuk iklan yang dibuat bloomka sesuai dengan target audien. Selanjutnya dan nilai rata-rata (mean) terkecil pada butir pernyataan GPO4 dengan nilai sebesar 4,42. Angka tersebut menunjukan ratarata responden setuju dengan pernyataan "Pesan yang digunakan mengajak konsumen untuk melestarikan lingkungan" yang artinya iklan yang dibuat bloomka mengajak konsumen untuk ikut melestarikan lingkungan. Selanjutnya, pada tabel tersebut terlihat bahwa nilai minimum setiap butir pernyataan variabel keputusan penggunaan para responden memberikan dengan nilai skor 3 dan nilai maksimum yang diberikan oleh reponden dengan nilai skor 5 . Nilai standar deviasi pada setiap butir pernyataan variabel Green Promotion memiliki nilai lebih kecil dari nilai rata-rata (mean) menunjukan sebaran variasi data variabel yang kecil atau tidak adanya kesenjangan penyimpangan data yang cukup besar.

\section{Uji Validitas}

Hasil uji validitas indikator pada variable dalam penelitian ini yang dibantu menggunakan Smart PLS 3.0.

Tabel 7. Statistik Deskriptif Variabel Green Promotion

\begin{tabular}{|c|c|c|c|c|c|}
\hline & $\begin{array}{l}\text { Kepuasan } \\
\text { Pelanggan }(\mathrm{Y})\end{array}$ & $\begin{array}{l}\text { Green } \\
\text { Product (X1) }\end{array}$ & $\begin{array}{l}\text { Green } \\
\text { Price (X2) }\end{array}$ & $\begin{array}{l}\text { Green } \\
\text { Place (X3) }\end{array}$ & $\begin{array}{l}\text { Green } \\
\text { Promotion (X4) }\end{array}$ \\
\hline$\overline{\mathrm{KP} 1}$ & 0,749 & & & & \\
\hline$\overline{\mathrm{KP} 2}$ & 0,693 & & & & \\
\hline KP3 & 0,790 & & & & \\
\hline$\overline{\mathrm{KP} 4}$ & 0,825 & & & & \\
\hline$\overline{\text { KP5 }}$ & 0,792 & & & & \\
\hline$\overline{\text { KP6 }}$ & 0,732 & & & & \\
\hline KP7 & 0,765 & & & & \\
\hline$\overline{\text { KP8 }}$ & 0,693 & & & & \\
\hline$\overline{\mathrm{GP} 2}$ & & 0,767 & & & \\
\hline$\overline{\mathrm{GP} 3}$ & & 0,737 & & & \\
\hline$\overline{\mathrm{GP} 4}$ & & 0,746 & & & \\
\hline$\overline{\text { GP5 }}$ & & 0,701 & & & \\
\hline$\overline{\text { GP6 }}$ & & 0,651 & & & \\
\hline$\overline{\text { GP7 }}$ & & 0,821 & & & \\
\hline$\overline{\text { GP8 }}$ & & 0,765 & & & \\
\hline$\overline{\text { GP9 }}$ & & 0,681 & & & \\
\hline$\overline{\text { GP10 }}$ & & 0,562 & & & \\
\hline$\overline{\mathrm{GPC} 1}$ & & & 0,694 & & \\
\hline$\overline{\mathrm{GPC} 2}$ & & & 0,794 & & \\
\hline$\overline{\mathrm{GPC} 4}$ & & & 0,502 & & \\
\hline$\overline{\text { GPC5 }}$ & & & 0,715 & & \\
\hline$\overline{\text { GPC6 }}$ & & & 0,737 & & \\
\hline$\overline{\text { GPC7 }}$ & & & 0,854 & & \\
\hline$\overline{\text { GPC8 }}$ & & & 0,692 & & \\
\hline$\overline{\text { GPL1 }}$ & & & & 0,725 & \\
\hline
\end{tabular}




\begin{tabular}{ll}
\hline GPL2 & 0,748 \\
\hline GPL3 & 0,674 \\
\hline GPL4 & 0,788 \\
\hline GPL5 & 0,765 \\
\hline GPL6 & 0,662 \\
\hline GPL7 & 0,784 \\
\hline GPL8 & 0,781 \\
\hline GPL9 & 0,817 \\
\hline GPL10 & 0,783 \\
\hline GPO1 & 0,733 \\
\hline GPO2 & 0,771 \\
\hline GPO3 & 0,735 \\
\hline GPO4 & 0,667 \\
\hline GPO5 & 0,775 \\
\hline GPO6 & 0,796 \\
\hline GPO7 & 0,771 \\
\hline GPO8 & 0,787 \\
\hline GPO9 & 0,702 \\
\hline GPO10 & 0,799 \\
\hline
\end{tabular}

Sumber: Data Diolah

\section{Model Indikator Reflektif}

Langkah pertama dalam model pengukuran adalah menguji model dengan convergent validity apakah nilai loading factor pada tiap konstruk sudah memenuhi convergent validity dengan outer model. Sehingga hal tersebut akan menjelaskan hubungan indikator dengan variable latennya. Hasil dari uji validitas diagram jalur awal Smart PLS 3.0 dapat dilihat pada diagram jalur dibawah.

\section{Model Pengukuran (Outer Model)}

Hasil dari uji validitas dengan menggunakan jalur awal aplikasi SmartPLS menunjukkan diagram jalur awal yang terbentuk. Tujuan dibentuknya diagram tersebut adalah untuk menguji apakah model telah dapat memenuhi convergent validity, yaitu apakah loading factor dalam setiap pernyataan mengenai citra merek, kualitas produk dan keputusan pembelian dapat memenuhi convergent validity. Diagram jalur yang dihasilkan adalah sebagai berikut: 


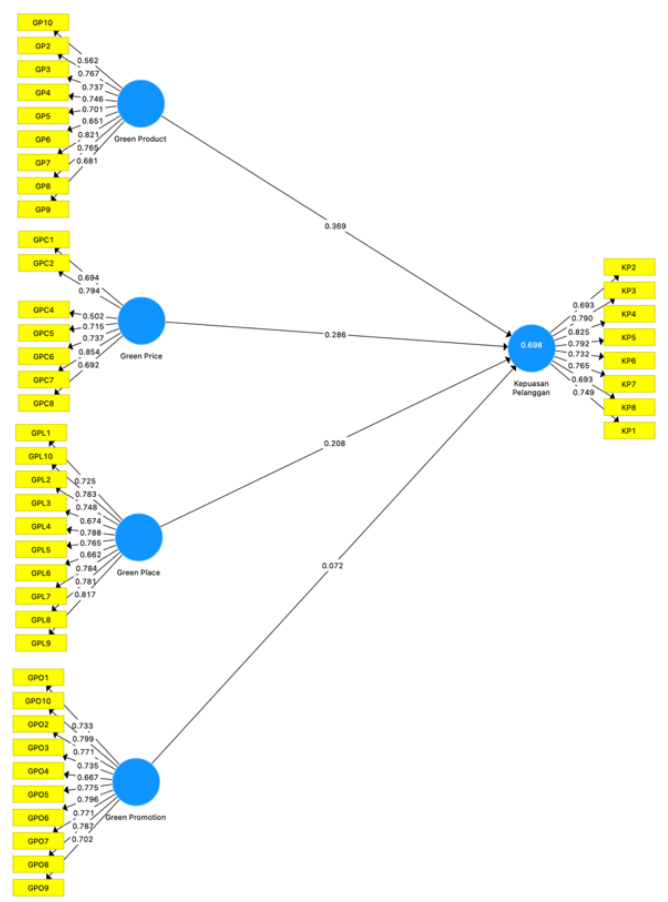

"Indikator bisa dianggap valid jika telah memiliki nilai korelasi diatas 0,7 namun pada riset tahap pengembangan skala loading 0,5 sampai 0,6 masih dapat diterima" (Noor, 2014 hlm.157). Dari hasil dari gambar diatas dapat diambil kesimpulan jika semua instrumen tentang variabel citra merek, kualitas produk, dan keputusan pembelian sudah memenuhi syarat dan dapat dinyatakan valid karena nilai dari loading factor telah memenuhi kriteria $>0,5$. Oleh karena itu peneliti dapat melanjutkan pengujian data selanjutnya.

\section{Average Variance Extracted (AVE)}

Berikut ini merupakan nilai dari Average Variance Extracted (AVE) masing-masing instrumen indikator:

Tabel 8. Average Variance Extracted (AVE)

\begin{tabular}{ll}
\hline Variabel & Average Variance Extracted (AVE) \\
\hline Kepuasan Pelanggan $(\mathrm{Y})$ & 0,572 \\
\hline Green Product $(X 1)$ & 0,516 \\
\hline Green Price $(X 2)$ & 0,518 \\
\hline Green Place $(X 3)$ & 0,569 \\
\hline Green Promotion $(X 4)$ & 0,570 \\
\hline
\end{tabular}

Sumber: Hasil output Smart PLS 3.0

Berdasarkan data diatas, dapat diketahui bahwa nilai AVE masing-masing variabel pada penelitian ini yaitu kepuasan pelanggan sebesar 0,572, green product sebesar 0,516 , green price sebesar 0,518, green place sebesar 0,569 dan green promotion sebesar 0,570. Suatu indikator dikatakan valid apabila memiliki nilai AVE lebih dari 0,5. Maka dapat disimpulkan bahwa konstruk kepuasan pelanggan, green product, green price, green place, dan green promotion adalah valid.

Sehingga dapat diartikan bahwa alat ukur yang digunakan dapat mengukur variabel kepuasan pelanggan, green product, green price, green place dan green promotion 


\section{Uji Reliabilitas}

\section{Composite Reliability}

Berikut ini merupakan nilai dari Composite Reliability masing-masing instrumen indikator sebagai berikut:

\begin{tabular}{ll}
\multicolumn{2}{l}{ Tabel 9. Average Variance Extracted $(A V E)$} \\
\hline Variabel & Composite Reliability \\
\hline Kepuasan Pelanggan $(\mathrm{Y})$ & 0,914 \\
\hline Green Product $(X 1)$ & 0,905 \\
\hline Green Price $(X 2)$ & 0,881 \\
\hline Green Place $(X 3)$ & 0,929 \\
\hline Green Promotion $(X 4)$ & 0,930 \\
\hline \multicolumn{2}{r}{ Sumber: Hasil output Smart PLS 3.0 }
\end{tabular}

Tabel diatas menunjukan nilai composite reliability terendah pada penelitian ini terdapat pada variabel green price yaitu sebesar 0,881 dan yang tertinggi adalah green promotion sebesar 0,930 . Suatu variabel dikatakan reliabel apabila nilai composite reliability berada diatas 0,7 sehingga dapat disimpulkan bahwa seluruh variabel memiliki reliabilitas yang baik terhadap masing-masing konstruk. Adapun uji reliabilitas dapat dilihat dengan cronbach's alpha dalam penelitian ini dimana dapat dilihat pada tabel berikut:

\section{Croanbach's Alpha}

Berikut ini merupakan nilai pada Croanbach's Alpha masing-masing instrumen indikator sebagai berikut:

Tabel 10. Average Variance Extracted (AVE)

\begin{tabular}{ll}
\hline Variabel & Cronbach's Alpha \\
\hline Kepuasan Pelanggan (Y) & 0,892 \\
\hline Green Product $(X 1)$ & 0,882 \\
\hline Green Price (X2) & 0,841 \\
\hline Green Place (X3) & 0,916 \\
\hline Green Promotion (X4) & 0,916 \\
\hline
\end{tabular}

Sumber: Hasil output Smart PLS 3.0

Tabel diatas menunjukan nilai cronbach's alpha yang diperoleh pada penelitian ini. Dapat diketahui bahwa masing-masing nilai cronbach's alpha pada kelima variabel ini adalah nilai paling terendah sebesar 0,841 pada variabel green price dan tertinggi adalah 0,916 pada green place dan green promotion. Suatu item akan dikatakan reliabel apabila nilai cronbach's alpha nya adalah lebih dari 0,7 . Maka dapat disimpulkan bahwa semua variabel pada penelitian ini memiliki reliabilitas yang baik terhadap masing-masing konstruknya

\section{$\mathbf{R}^{2}$ (Koefisien Determinasi)}

Uji R Square merupakan uji goodness fit model. Dimana R Square digunakan untuk variable dependen, variable terikat atau variable endogen. Berikut adalah output software Smart PLS 3.0 pada R Square variable keputusan pembelian. 
Tabel 11. Nilai R-Square

\begin{tabular}{lll}
\hline Variabel & R Square & R Square Adjusted \\
\hline Kepuasan Pelanggan (Y) & 0,698 & 0,685 \\
\hline
\end{tabular}

Sumber: Hasil output Smart PLS 3.0

Berdasarkan tabel diatas, dapat diketahui bahwa besar R Square variabel kepuasan pelanggan pada penelitian ini adalah sebesar 0,685. Menurut Ghozali, nilai koefisien determinasi jika berada diantara nol dan satu dan hasilnya mendekati angka satu, maka dapat dikatakan bahwa variabel independent mampu memberikan informasi yang dibutuhkan untuk memprediksi variasi variabel dependen. Sehingga berdasarkan pernyataan tersebut nilai $\mathrm{R}$ square menunjukan bahwa kepuasan pelanggan dapat dijelaskan sebesar $68,5 \%$ oleh variabel green product, green price, green place dan green promotion. Sedangkan sisanya sebesar 31,5\% dapat dijelaskan oleh variabel lain yang tidak digunakan pada penelitian ini.

\section{Uji T Statistik}

Uji $\mathrm{t}$ adalah uji yang dilakukan untuk menunjukan seberapa jauh pengaruh suatu variabel independent terhadap kemampuan untuk menjelaskan variabel dependen atau untuk mengetahui pengaruh signifikan antara masing-masing variabel green product, green price, green place dan green promotion terhadap kepuasan pelanggan. Diketahui $\mathrm{t}$ tabel diperoleh melalui rumus $\mathrm{df}=\mathrm{n}-$ $\mathrm{k}$ atau $\mathrm{df}=100-5=95$, dan dihubungkan dengan derajat kepercayaan $10 \%$ atau 0,1 . Adapun hasil dari pengolahan data untuk pengujian signifikansi (uji t) diperoleh hasil sebagai berikut:

Tabel 12. T Statistic

\begin{tabular}{|c|c|c|c|c|c|}
\hline & $\begin{array}{l}\text { Original } \\
\text { Sample }(O)\end{array}$ & $\begin{array}{l}\text { Sample } \\
\text { Mean }(M)\end{array}$ & $\begin{array}{l}\text { Standard Deviation } \\
\text { (STDEV) }\end{array}$ & $\begin{array}{l}T \quad \text { Statistics } \\
(|O / S T D E V|)\end{array}$ & $\begin{array}{l}P \\
\text { Value } \\
s \\
\end{array}$ \\
\hline $\begin{array}{l}\text { Green Place (X3)-> Kepuasan } \\
\text { Pelanggan }(\mathrm{Y})\end{array}$ & 0.208 & 0.213 & 0.101 & 2.051 & 0.041 \\
\hline $\begin{array}{l}\text { Green Price (X2) -> Kepuasan } \\
\text { Pelanggan (Y) }\end{array}$ & 0.286 & 0.282 & 0.115 & 2.493 & 0.013 \\
\hline $\begin{array}{l}\text { Green Product (X1)-> Kepuasan } \\
\text { Pelanggan (Y) }\end{array}$ & 0.369 & 0.357 & 0.112 & 3.307 & 0.001 \\
\hline $\begin{array}{lll}\text { Green Promotion } & \text { (X4)-> } \\
\text { Kepuasan Pelanggan } & \\
\end{array}$ & 0.072 & 0.090 & 0.108 & 0.663 & 0.507 \\
\hline
\end{tabular}

Dalam penelitian ini, pengaruh antara variabel dependen dan independent dapat diketahui menggunakan hasil olah data $t$ statistic dan $p$ value yang terdapat pada output smart PLS. Hasil $\mathrm{t}$ statistic digunakan untuk mengetahui pengaruh suatu variabel apakah positif atau negatif. Suatu variabel dikatakan positif apabila nilai t hitungnya lebih besar dari t tabel. Sedangkan $\mathrm{p}$ values diperuntukan untuk mengetahui apakah variabel tersebut signifikan ataupun tidak. Suatu variabel akan dikatakan signifikan apabila nilai p values kurang dari 0,05. Dapat diketahui bahwa melalui tabel 16, hasil pengujian variabel green product terhadap kepuasan pelanggan menunjukan nilai $\mathrm{t}$ hitung sebesar 3,307>t tabel 1,290 dan nilai signifikan yang dapat dilihat melalui kolom $\mathrm{p}$ values sebesar $0,001<0,1$. Dapat disimpulkan bahwa variabel green product berpengaruh positif dan signifikan terhadap kepuasan pelanggan yang berarti hipotesis 1 diterima.

Berdasarkan tabel diatas dapat diketahui bahwa green price menunjukan nilali t hitung sebesar 2,493 > t tabel 1,290 dan nilai signifikan yang dapat dilihat melalui kolom $\mathrm{p}$ values sebesar $0,013<0,1$. Dapat disimpulkan bahwa variabel green price memiliki pengaruh positif dan signifikan terhadap kepuasan pelanggan yang berarti hipotesis 2 diterima 
Berdasarkan tabel diatas dapat diketahui bahwa variabel green place menunjukan nilai $\mathrm{t}$ hitung sebesar 2,051 > t tabel 1,290 dan nilai signifikan yang dapat dilihat melalui kolom $\mathrm{p}$ values sebesar $0,041<0,1$. Dapat disimpulkan bahwa variabel green place memiliki pengaruh positif dan signifikan terhadap kepuasan pelanggan yang berarti hipotesis 3 diterima

Berdasarkan tabel diatas dapat diketahui bahwa variabel green promotion menunjukan nilai $\mathrm{t}$ hitung sebesar 0,663 < t tabel 1,290 dan nilai signifikan yang dapat dilihat melalui kolom $\mathrm{p}$ values sebesar $0,507>0,1$. Dapat disimpulkan bahwa variabel green promotion memiliki pengaruh negatif dan tidak signifikan terhadap kepuasan pelanggan yang berarti hipotesis 4 diterima

\section{Pembahasan}

Berdasarkan hasil penelitian mengenai green product, green price, green place, dan green promotion terhadap kepuasan pelanggan yang menggunakan metode Partial Least Square (PLS) dengan software Smart PLS 3.0, diperoleh sebuah hasil yaitu:

\section{Pengaruh Green Product terhadap Kepuasan Pelanggan}

Berdasarkan hasil pengolahan pada uji t, menunjukan bahwa variabel green product berpengaruh terhadap kepuasan pelanggan, sehingga dapat diartikan bahwa green product memiliki hubungan yang positif dan berpengaruh signifikan terhadap kepuasan pelanggan.

Uji hipotesis menunjukan hasil bahwa green product berpengaruh positif dan signifikan terhadap kepuasan pelanggan dengan nilai ukur koefisien jalur sebesar 0,369. Artinya ketika green product mengalami peningkatan, maka kepuasan pelanggan akan meningkat sebesar 0,369. Demikian pula, jika green product menurun, maka kepuasan pelanggan juga akan menurun.

Dalam hal ini, dapat diketahui bahwa indikator-indikator yang terdapat pada green product berupa bahan alami, produk ramah lingkungan, daur ulang kemasan, produk bersertifikasi, daya tahan produk. Indikator ini akan dapat meningkatkan green product untuk kepuasan pelanggan bloomka skincare. Sehingga dapat dianggap telah memberikan kontribusi yang besar terhadap perannya dalam mempengaruhi kepuasan pelanggan bloomka skincare.

Pernyataan ini didukung oleh penelitian yang dilakukan oleh Muhammad Husnan Zaky (2020) yang menyatakan green product berpengaruh positif dikarenakan jika green product ditingkatkan dengan meningkatkan kualitas produk menggunakan bahan yang lebih alami sehingga lebih menarik dan memberikan informasi kepada konsumen dalam usaha meningkatkan kesadaran konsumen akan kesehatan. Serta penelitian yang dilakukan oleh Stevany Febriani (2019) yang menyatakan bahwa green product berpengaruh terhadap kepuasan pelanggan. Maka dalam penelitian ini, hipotesis yang telah disusun sebelumnya yaitu $\mathrm{H}_{1}$ diterima.

\section{Pengaruh Green Price terhadap Kepuasan Pelanggan}

Berdasarkan hasil pengolahan pada data uji t, menunjukan bahwa variabel green price berpengaruh terhadap kepuasan pelanggan. Sehingga dapat diartikan bahwa green product memiliki hubungan yang positif dan berpengaruh signifikan terhadap kepuasan pelanggan.

Uji hipotesis menunjukan hasil bahwa green price berpengaruh positif dan signifikan terhadap kepuasan pelanggan dengan nilai koefisien jalur sebesar 0,286. Artinya ketika green price mengalami peningkatan, makan kepuasan pelanggan akan meningkat sebesar 0,286. Demikian pula, jika green price menurun, maka kepuasan pelanggan juga akan menurun. Indikatorindikator yang digunakan dalam variabel green price berupa biaya untuk kesehatan, biaya dengan manfaat lingkungan, diskon harga dan harga premium. Indikator ini dapat meningkatkan pengaruh green price dalam mempengaruhi kepuasan pelanggan bloomka skincare.

Hasil tersebut menunjukan bahwa responden setuju green price yang dikeluarkan saat membeli product bloomka termasuk dengan biaya untuk kesehatan sehingga mendapat dua manfaat dalam 
satu transaksi. Dengan membeli bloomka juga termasuk responsibility pelanggan untuk memberi manfaat kepada lingkungan dengan menjaga dan memanfaatkannya dengan baik. Diskon harga yang diberikan juga membantu konsumen untuk mendapatkan kegiatan pembelian yang nyaman. Responden juga setuju bahwa green price yang diberikan bloomka merupakan harga premium dengan mendapatkan beberapa manfaat dalam pembelian. Dapat dikatakan variabel green price dan indikator-indikatornya berkontribusi terhadap perannya dalam mempengaruhi kepuasan pelanggan

Pernyataan ini didukung oleh penelitian yang dilakukan oleh Steve Setio \& Denny Bernardus Kurnia Wahjudono (2020) yang menyatakan green price berpengaruh positif dan menyatakan bahwa price yang dimiliki oleh bloomka skincare seperti harga sesuai dengan kualitas, harga sesuai dengan fasilitas memiliki pengaruh dalam kepuasan pelanggan. Selanjutnya, penelitian lain yang dilakukan oleh Niken Yulinasari (2017) yang menyatakan bahwa green price berpengaruh positif terhadap kepuasan pelanggan. ini sejalan dengan Thoria Omer Mahmoud (2018) yang menyatakan bahwa green price berpengaruh positif terhadap kepuasan pelanggan. Maka dalam penelitian ini, hipotesis yang telah disusun sebelumnya yaitu $\mathrm{H}_{2}$ diterima

\section{Pengaruh Green Place Terhadap Kepuasan Pelanggan}

Berdasarkan hasil pengolahan pada data uji t, menunjukan bahwa variabel green place berpengaruh terhadap kepuasan pelanggan. Sehingga dapat diartikan bahwa green place memiliki hubungan yang positif dan berpengaruh signifikan terhadap kepuasan pelanggan.

Uji hipotesis menunjukan hasil bahwa green place berpengaruh positif dan signifikan terhadap kepuasan pelanggan dengan nilai koefisien jalur sebesar 0,208. Artinya ketika green place mengalami peningkatan, makan kepuasan pelanggan akan meningkat sebesar 0,208. Demikian pula, jika green place menurun, maka kepuasan pelanggan juga akan menurun. Indikatorindikator yang digunakan dalam variabel green place berupa lokasi strategis, lokasi hijau, kelengkapan produk, outlet bertema lingkungan dan parkir yang nyaman. Indikator ini dapat meningkatkan pengaruh green place dalam mempengaruhi kepuasan pelanggan bloomka skincare.

Hasil tersebut menunjukan bahwa responden setuju lokasi yang strategis memberikan kemudahan konsumen untuk mendapatkan product bloomka dengan menerapkan lokasi yang hijau dengan outlet yang bertema lingkungan untuk tetap menjaga kelestarian lingkungan sehingga mendukung dalam pelestarian lingkungan dan memberikan sugesti kepada konsumen untuk melestarikan lingkungan dan dengan menyediakan berbagai product yang dijual agar konsumen dapat mendapatkan product bloomka dengan mudah serta menyediakan parkir yang nyaman.

Dapat dikatakan variabel green place dan indikator-indikatornya berkontribusi terhadap perannya dalam mempengaruhi kepuasan pelanggan. Studi sebelumnya terutama berfokus pada tempat-tempat ramah lingkungan sehingga sebagian besar konsumen lebih suka melakukan pembelian di tempat-tempat yang tidak berpolusi (Dr. Arvin Lucy, 2016)

Hasil penelitian ini sejalan dengan penelitian yang dilakukan oleh Athavia Herawati (2020) yang menyatakan bahwa green place berpengaruh terhadap kepuasan pelanggan serta penelitian lainnya dilakukan oleh Agnes Viani Parlan, Andriani Kusumawati (2016) yang menyatakan bahwa green place berpengaruh terhadap kepuasan pelanggan. Maka dalam penelitian in, hipotesis yang telah disusun sebelunya yaitu $\mathrm{H}_{3}$ diterima.

\section{Pengaruh Green Promotion Terhadap Kepuasan Pelanggan}

Berdasarkan hasil pengolahan pada data uji t, menunjukan bahwa variabel green promotion tidak berpengaruh terhadap kepuasan pelanggan. Sehingga dapat diartikan bahwa green promotion memiliki hubungan yang negatif dan tidak berpengaruh signifikan terhadap kepuasan pelanggan. 
Uji hipotesis menunjukan hasil bahwa green promotion tidak berpengaruh positif dan tidak signifikan terhadap kepuasan pelanggan dengan nilai koefisien jalur sebesar 0,072. Artinya kepuasan pelanggan tidak mengalami peningkatan maupun penurunan berapapun nilai green promotion tersebut. Indikator-indikator yang digunakan dalam variabel green promotion berupa ketepatan media periklanan, pesan produk ramah lingkungan, iklan memperkuat image produk, iklan menjadi panduan informasi dan loyalitas konsumen. Indikator ini tidak dapat meningkatkan pengaruh green promotion dalam mempengaruhi kepuasan pelanggan bloomka skincare.

Tidak berpengaruhnya green promotion terhadap kepuasan pelanggan didukung oleh penelitian yang dilakukan oleh Shinta Wahyu Hati dan Afriani Kartika (2015) yang menyatakan bahwa green promotion tidak berpengaruh terhadap kepuasan pelanggan. Pernyataan ini didukung oleh Steve Setio \& Denny Bernardus Kurnia Wahjudono (2020) yang menyatakan tujuan dilakukannya promosi adalah untuk mengkomunikasikan suatu produk agar pelanggan yang dituju terbujuk oleh pesan yang disampaikan dan memutuskan untuk membeli sehingga tidak memengaruhi kepuasan pelanggan. Maka dalam penelitian ini, hipotesis yang telah disusun sebelumnya yaitu $\mathrm{H}_{4}$ ditolak

\section{KESIMPULAN DAN SARAN}

\section{Kesimpulan}

Berdasarkan analisis serta pengujian hipotesis maka diperoleh hasil yaitu, green product berpengaruh terhadap kepuasan pelanggan pada kepuasan pelanggan produk bloomka. Artinya ketika green product mengalami peningkatan, maka kepuasan pelanggan akan meningkat. Demikian pula, jika green product menurun, maka kepuasan pelanggan juga akan menurun.

Selanjutnya, hasil penelitian membuktikan dan menunjukan bahwa green price berpengaruh terhadap kepuasan pelanggan pada bloomka skincare. Artinya ketika green price mengalami peningkatan, makan kepuasan pelanggan akan meningkat. Demikian pula, jika green price menurun, maka kepuasan pelanggan juga akan menurun.

Kemudian, hasil penelitian membuktikan dan menunjukan bahwa green place berpengaruh terhadap kepuasan pelanggan pada bloomka skincare. Artinya ketika green place mengalami peningkatan, makan kepuasan pelanggan akan meningkat. Demikian pula, jika green place menurun, maka kepuasan pelanggan juga akan menurun

Selanjutnya hasil penelitian membuktikan dan menunjukan bahwa green promotion tidak berpengaruh terhadap kepuasan pelanggan pada bloomka skincare. Artinya kepuasan pelanggan tidak mengalami peningkatan maupun penurunan berapapun nilai green promotion tersebut

\section{Saran}

Berdasarkan analisis, pembahasan serta kesimpulan yang telah disusun, maka penulis dapat memberikan beberapa saran terkait hasil penelitian yang bertujuan dan diharapkan dapat berguna untuk masyarakat, perusahaan, peneliti selanjutnya atau pihak-pihak yang membutuhkannya yaitu sebagai berikut :

a. Perusahaan ataupun industry e-commerce dapat menjadikan penelitian ini sebagai referensi dalam meningkatkan strategi pemasaran. Dimana dengan meningkatkan green product, green price, green place dan green promotion yang akan berdampak bagi kepuasan pelanggan.

Berdasarkan uraian dalam pembahasan terkait kepuasan pelanggan dapat disarankan bloomka perlu menpertahan harga yang sesuai dengan fasilitas yang diberikan kepada konsumen dan meningkatkan produk agar sesuai dengan apa yang konsumen harapkan, lalu pada green product, bloomka perlu mempertahankan bahan yang berbahan dasar tumbuhan sebagai bahan dasar produknya, serta meningkatkan daya tahan produknya. Terkait green price, bloomka sebaiknya dapat mempertahankan potongan harga agar memicu konsumen 
untuk membeli produk dan meningkatkan harga yang dapat membantu konsumen tetap menjaga kelestarian lingkungan. Selanjutnya green place, bloomka dapat mempertahankan lokasi toko agar mudah dijangkau konsumen dan meningkatkan lahan parkir yang luas.

b. Bagi peneliti selanjutnya

Saran untuk peneliti selanjutnya, dapat dilakukan pengembangan terhadap penelitian menggunakan tema sejenis, dengan menambahkan atau mengganti variabel penelitian seperti impulse buying dan greem lifestyle.

\section{Ucapan Terima Kasih (Acknowledgement)}

Penelitian ini tidak akan berhasil tanpa ada bantuan dari beberapa pihak lain. Oleh karena itu pada kesempatan ini, penulis ingin mengucapkan terima kasih sebesar-besarnya pada semua pihak yang telah membantu penulis dalam menyusun penelitian ini. Dengan segala kerendahan hati, penulis mengucapkan terima kasih khususnya kepada kedua orang tua dan keluarga yang tiada hentinya selalu memberikan doa serta dukungan kepada penulis, bu Dr. Miguna Astuti, S.Si., M.M., MOS, CPM. selaku Dosen Pembimbing 1 sekaligus Penguji 2, Ibu Dienni Ruhjatini Sholihah, S.E., M.M selaku Dosen Pembimbing 2, Bapak Drs. Nobelson, MM selaku Ketua Dosen Penguji, Bapak Jenji Gunaedi Argo, SE, MM selaku Dosen Penguji dan teman-teman terdekat penulis yang selalu memberikan dukungannya.

\section{REFERENSI}

Agnes Viani Parlan, Andriani Kusumawati, M. K. M. (2016). The Effect of Green Marketing Mix on Purchase Decision And Customer Satisfction (Study on Independent Consultant of JAFRA Cosmetics Indonesia in Malang)". Jurnal Administrasi Bisnis S1 Universitas Brawijaya, Vol. 39.

Akter, S. (2012). The Role of Microinsurance as a Safety Net Against Environmental Risks in Bangladesh. The Journal of Environment \& Development.

Ali, H. (2015). Tourism Marketing. Center for Academic Publishing Service.

Alma Buchari. (2014). Manajemen Pemasaran dan Pemasaran Jasa. Bandung: CV. Alfabeta.

Aman Diglel, A. P. D. R. Y. (n.d.). Green Marketing: It's Influence on Buying Behavior and Attitudes of the Purchasers towards Eco-Friendly Products.

Athavia Herawati. (2020). Pengaruh Green Marketing Mix terhadap Green Purchase Intention Dalam Menggunakan Eco Friendly Product (Studi Kasus Pada Sedotan Stainless Steel)”.

B Suryawardani \& A Wulandari. (2019). Green Product: Its Impacts on Environmental Safety and Customer Satisfaction. International Journal of Engineering \& Technology.

Basu, S. (2010). Manajemen Pemasaran: Analisa dan Perilaku Konsumen.

Brigita Inggrid Noviana. (2013). Pengaruh Service Marketing Mix Terhadap Kepuasan Konsumen Hotel Amaris Surabaya. Jurnal Hospitality Dan Manajemen Jasa, Vol 1, No.

Collins Marfo Agyeman. (2014). Consumers' Buying Behavior Towards Green Products: An Exploratory Study. International Journal of Management Research and Business Strategy, Vol 3, No.

Deasy Lestary Kusnandar, L. R. R. (2017). The Effect of Green Marketing on Purchase Decision with Brand Image as Mediating Variable. Jurnal Akuntasi, Manajemen Dan Ekonomi, Vol 19 No.

Dimas Ifanda Putra Kusuma. (2020). Pengaruh Kualitas Produk, Citra Merek Terhadap Loyalitas Pelanggan Melalui Kepuasan Pelanggan. Jurnal Ilmu Dan Riset Manajemen, Volume 9,(eISSN: 2461-0593).

Dr. M.Anang Firmansyah, S.E., M. M. (2018). PERILAKU KONSUMEN (Sikap dan Pemasaran). Jawa Tengah: Penerbit Qiara Media, 2019. 
Erciş, M. S., \& Çat, A. K. (2016). Green Marketing and the Green Product Buying Behaviors of Consumers: An Application in Ataturk University. Online Journal of Communication and Media Technologies, Volume: 6(2 April).

Etta Mamang Sangadji \& Dr. Sopiah. (2013). Perilaku Konsumen.

Febriani, S. (2019). Pengaruh Green Marketing Mix Terhadap Green Product Purchase Intention Pada Produk Innisfree Di Jakarta Dengan Consumer's Attitude Sebagai Variabel Mediasi. Jurnal Manajemen Bisnis Dan Kewirausahaan, 3(1), 49-61. https://doi.org/10.24912/jmbk.v3i1.4925

Ferdinand, A. (2018). Metode Penelitian Manajemen Pedoman Penelitian untuk Penulisan Skripsi Tesis dan Disertasi Ilmu Manajemen. Semarang: Badan Penerbit Universitas Diponegoro.

Ghozali. (2014). Aplikasi analisis Multivariate dengan Program SPSS. Semarang: Badan Penerbit UNDIP.

Ghozali, I. (2015). Partial Least Square (2nd ed.). Semarang: Badan Penerbit Universitas Diponogoro.

Ghozali, Imam. (2016). Aplikasi Analisis Multivariete dengan Program IBM SPSS 23. Semarang: Badan Penerbit Universitas Diponegoro.

Ghozali, Imam. (2018). Aplikasi Analisis Multivariate (9th ed.). Semarang: Badan Penerbit Universita Diponegoro.

Govender, J. P., \& Govender, T. L. (2016). The influence of green marketing on consumer purchase behavior. Environmental Economics.

Hashem and Al-Rifai. (n.d.). The Influence of Applying Green Marketing Mix by Chemical Industries Companies. International Journal of Business and Social Science.

Hery, S. . (2019). Manajemen Pemasaran.

Hunt, S. D. (1991). Modern Marketing Theory. Critical Issues in the Philosophy of Marketing Science.

Kontic, I. (2010). Greening the marketing mix: A case study of the Rockwool Group (online). Jönköping International Business School.

Lucy, D. A. (2016). Green Marketing and Consumer Satisfaction. Journal of Marketing and Consumer Research, Vol.29.

Muhammad Husnan Zaky, N. M. P. (2020). Green Marketing Mix Berpengaruh Terhadap Keputusan Pembelian Produk Big Tree Farms di Lotus Food Services. E-Jurnal Manajemen, Vol 9, No.

Muhammed Abdullah Sharaf, S. P. (2018). An Overview Profile and Green Purchasing Behavior of Consumers in the Northern Region of Malaysia. Journal of Research in Marketing, Vol 8 No 3 .

N.A.S.A Sabri, N. Mansor, H. M. (2020). The Influence of Green Marketing Mix on Consumer Purchase Intention Towards Green Products. International Journal of Human and Technology Interaction, Vol 4, No.

Niken Yulinasari. (2017). Pengaruh Affordability Price Dan Product Quality Terhadap Kepuasan Pelanggan Pada Kosmetik Green Product.

Noor, J. (2014). Metodologi Penelitian: Skripsi, Tesis, Disertasi dan Karya Ilmiah. Jakarta: Kencana.

Noor, Juliansyah. (2014). Analisis Data Penelitian Ekonomi \& Manajemen. Jakarta: PT Grasindo.

P. Kotler and K.L.Keller. (2016). Manajemen Pemasaran (15th ed.). Erlangga.

Pamungkas, G. I., Prasodjo, A., \& Indraningrat, K. (2015). Pengaruh Green Product Dan Green Advertsing Terhadap Keputusan Pembelian Lampu LED Philips Di Jember. Artikel Ilmiah Mahasiswa. 
Pankaj dan Vishal. (2014). Consumer adoption of green products and their role in resource management. Indian Journal of Commerce \& Management Studies.

Peter, J. P., \& Olson, J. C. (2013). Perilaku Konsumen dan Strategi Pemasaran (9th ed.). Jakarta: Penerbit Salemba Empat.

Philip Kotler dan Gary Amstrong. (2018). Principles of Marketing (Edisi 15 G).

Rambalak Yadav and Govind S. Pathak. (2017). Determinants of Consumers' Green Purchase Behavior in a Developing Nation: Applying and Extending the Theory of Planned Behavior. Ecological Economics, Vol. 134(Issue C).

Reza, M. A., Leila, A. G., \& Vostac, N. (2014). Analysing the Effect of Social Media on Brand Attitude and Purchase Intention: The Case of Iran Khodro Company. Procedia - Social and Behavioral Sciences, Volume 143.

Rizal Ahmad, R. H. M. E. F. (2020). Strategi Megembangkan Kepuasan Pelanggan Online Shop dalam Meningkatkan Penjualan (Studi Kasus Sabun Pyari). Jurnal Manajemen Tools, Vol 12 No.

Samsul Ramli \& Fahrurrazi. (2013). Bacaan Wajib Swakelola Pengadaan Barang/Jasa Pemerintah. Jakarta: Visi Media Pustaka.

Sandy, F. (2020). Ekspor Tembus Rp 4,4 T, Industri Kosmetik \& Farmasi RI Cuan. CNN Indonesia.

Savitri, A. (2016). Basmi Penyakit Dengan TOGA (Tanaman Obat Keluarga).

Shinta Wahyu Hati. (2015). Pengaruh Green Marketing Terhadap Kepuasan Pelanggan Produk Kosmetik Merk The Body Shop (Studi pada Mahasiswi Jurusan Manajemen Bisnis di Politeknik Negeri Batam yang Menggunakan Produk Kosmetik Merek The Body Shop). Jurnal Akuntansi, Ekonomi Dan Manajemen Bisnis, VOL 3 NO 2.

Steve Setio \& Denny Bernardus Kurnia Wahjudono. (2020). Pengaruh Marketing Mix terhadap Kepuasan dan Loyalitas Customer Hotel Amaris Darmo Surabaya. Ekuitas Jurnal Ekonomi Dan Keuangan, Vol 4 No 3.

Sugiyono. (2019). Metode Penelitian Kuantitatif, Kualitatif dan R\&D. Bandung: Alfabeta CV.

Sutopo, E. Y., \& Slamet, A. (2017). Statistika Inferensial (Giovanny, ed.). Yogyakarta: Penerbit Andi.

Thoria Omer Mahmoud. (2018). Impact of Green Marketing Mix on Purchase Intention. International Journal of Advanced and Applied Sciences, Vol 5. 
Seminar Nasional Hasil Penelitian dan Pengabdian Kepada Masyarakat 2021

Pengembangan Ekonomi Bangsa Melalui Inovasi Digital Hasil Penelitian dan

Pengabdian Kepada Masyarakat

Jakarta, 21 Oktober 2021

(halaman kosong) 